\title{
Краткий обзор Исламского налогообложения Христиан и Иудеев (зимми) на территории Средней Азии в средневековье
}

\author{
Nazgul KALíLOVA ${ }^{1}$
}

\section{Аннотация}

Статья посвящена вопросам исламского налогообложения христиан и иудеев (зимми) в Средней Азии. Направление исследования явАяется проблемой общего и особенного в понятии налогообложения ислама, иудаизма и христианства. Работа нацелена на исламскую правовую основу функционирования налоговой системы в завоёванных мусульманами территориях Средней Азии. В статье были выявлены причины появления новых налогов в исламе, определяется термин и положение зимми, разница межАу зимми и неверными, характер взаимодействий мусульман с Аругими преАставителями монотеистических религий, определяется степень общественно-политической жизни региона межАу мусульманами и представителями зимми. Выявлено, что Каноны ислама играют главную роль во взаимоотношении мусульман с Аругими конфессиями. На основе анализа, а также при использовании специально-историческими методами (историко-сравнительными, сравнительно-сопоставительными методиками), были выявлены степень схожести и разАичия налогообложения, проблемы христиано-еврейского взаимоотношения в Европе. В слеАствии которого в статье раскрываются причины частичного переселения и Аальнейшего социально экономического положения и развития евреев и христиан в Средней Азии.

Ключевые Слова: Ислам, Христианство, Иудаизм, Аюди Писания, Зимми, Налоги

Orta Çağ'da Orta Asya'da Hıristiyan ve Yahudilerin (zimmi) İslami Vergilendirilmesine Kısa Bir Bakış

Özet

Makale, Orta Asya'daki Hristiyanlar ve Yahudilerin (zimmi) İslami vergilendirilmesi meselelerine ayrılmıştır. Araştırmanın yönü, İslam ve Hıristiyanlığın vergilendirilmesi kavramında genel ve özel bir sorundur. Çalışma, Orta Asya'nın Müslümanların fethettiği topraklarda vergi sisteminin işleyişi için İslami yasal temeli hedefliyor. Makale, İslam'da yeni vergilerin ortaya çıkmasının nedenlerini tanımlıyor, zimmi terim ve konumunu, zimmiler ve kafirler arasındaki farkı, Müslümanların tek tanrılı dinlerin diğer temsilcileriyle olan etkileşimlerinin niteliğini, Müslümanlar ve zimmi temsilcileri arasındaki bölgenin sosyal ve siyasi yaşamının derecesini belirliyor. Müslümanların diğer itiraflarla ilişkilerinde İslam Kanunları'nın önemli bir rol oynadığı ortaya çıktı. Analiz temelinde, özel tarihsel yöntemlerin (tarihsel-karşılaştırmalı, karşılaştırmalı-karşılaştırmalı yöntemler) kullanılmasının yanı sıra, vergilendirmedeki benzerlik ve farklılıklar, Avrupa'daki Hıristiyan-Yahudi ilişkilerinin sorunları belirlendi. Bunun bir sonucu olarak makale, Orta Asya'daki Yahudilerin ve Hıristiyanların kısmi yeniden yerleşim ve daha fazla sosyo-ekonomik durum ve gelişme nedenlerini ortaya koymaktadır.

Anabtar Kelimeler: İslam, Hıristiyanlık, Musevilik, Kutsal Kitap Ehli, Zimmi, Vergiler

\section{Atıf İçin / Please Cite As:}

Kalilova, N. (2021). Краткий обзор исламского налогообложения христиан и иудеев (зимми) на территории Средней Азии в средневековье. Manas Sosyal Arastırmalar Dergisi, 10(4), 2473-2495.

Geliş Tarihi / Received Date: 02.11.2020

Kabul Tarihi / Accepted Date: 28.06.2021

\footnotetext{
${ }^{1}$ Nazgul KALİLOVA - Kırgizistan-Türkiye Manas Üniversitesi İlahiyat Fakültesi, nazgul.kalilova@manas.edu.kg 


\section{Введение}

МежАу исламом, иудаизмом и христианством сформировывались отношения не только на основе религиозных убеждений, но и на основе исторических обстоятельств. В результате этого исторический путь взаимоотношений межАу этими религиями стала основой Аля рационального религиозного понимания и восприятия ими Аруг-Аруга. В исторических этапах представители этих религий определялись как с указанием религиозной принадлежности, так и с указанием социальной, экономической или политической группы, в которой они находились. В преАставителях этих религиозных конфессий, которые находились внутри Аругих религий было заметны признаки культуры и особенностей Аоминирующей стороны. Культура в котором Аоминировал ислам как религия, особо не акцентироваА внимание на разАичие межАу нациями, цвета кожи и материального положения, в итоге Средняя Азия стала Аля христианства несторианского толка местом развития. В изначальном появ ении несторианства сыграло большую роль новые религиозные понятия в Византии, ${ }^{2}$ в результате этого от Византийской церкви откололся новое направление, основателем которого становиться архиепископ Константинополя Несториан. После смерти основателя его сторонники и преемники стали называться несторианами ${ }^{3}$ а их миссии были широко распространены в Средней Азии и сохраняли там свое влияние до середины 13 века. (Бемяев, 1998, стр. 91) Есть также археологические находки, которые указывают на переход местного населения (тюрков Средней Азии) в несторианство. Это указывает на то, что несторианскую религию исповедовали не только иностранцы-византийцы, но и местные тюркские народы. Практически во всех рассматриваемых археологических находках Средней Азии изображен крест - символ христианства. На некоторых памятниках нет надписей, только изображение креста. (Жумагулов, 2014, стр. 188-196). Что касается иудаизма появление первых евреев в Средней Азии относиться к 500 годам А.н.э. к эпохе правления державы Персидских Ахеменидов. Евреи до присоеденения к персиАской армии находились подвластью Нововалилонского царства, ${ }^{4}$ после их захвата Киром II евреи были освобождены и по их желанию присоеденены в перстАское войско, и именно в качестве воинов персиАской Аинастии евреи вступили на среднеазиатские земли., а в последствии были расселены в уже захваченных ими землях. (ФАавий, 1994, стр. 113-214). Напротяжении Авухстолетий в средневековье в среднеазиатском регионе иудеи жили с караханидами, газневидами, селджуками и хорезмшахами. C XII в. Средняя Азия не раз жестоко заваевывается монголами, заваевываются такие города как Бухара Самарканд, Ургент, Мерв и несмотря на это иудеи сохраняют свое существование в Средней Азии в средневековье. Взаимоотношение этих преАставителей монотеситических религий было разным, и именно их социально-экономическое положение и налогообложение является фактором, который обективно сможет показать их реальное взаимоотношение.

\section{НААОГООБАОЖЕНИЕ КАК ТАКОВОЙ В АОИСААМСКИХ ЦИВИАИЗАЦИЯХ}

Распространение религии ислам сыграло объединяющую роль в социально-экономической жизни вошедших стран Средней Азии в состав Исламской Империи. В начальных этапах, объединение привело экономическому и культурному слиянию захваченных городов, которые различались по экономическому уровню жизни, религией, традицией, стремительно начали развиваться города, торговые пути. Именно религия стала причиной расширения экономических связей, при которых каждая завоеванная часть вносила свой вклаА в общую экономику Исламской Империи. Мусульмане смогли создать эффективную налоговую систему, при котором наряду с наличными деньгами в торговых операциях, использовались безналичные расчеты. За короткий промежуток времени был установлен конкретный порядок в налогообложении которая была основана на Канонах Ислама - Коране и Сунне, которые в отличии от Аругих религий веками не меняются.

\footnotetext{
${ }^{2}$ Спор о том был Аи Иисус «истинным богом»

3 Академик В. В. Бартольд пишет, что среднеазиатские несториане не называли себя христианами или несторианами, название «несторианцы» не переводилось на восточные языки и они не фигурироваАи в наАписях Семиречья. Христиане в этой церкви называли себя христианами или назареями.

${ }^{4}$ 626-538 Ао н.э.
} 
Многие государства существовали только благодаря денежным поступлениям в казну, и это неизбежно вынуждало государства вмешиваться в экономику страны. Как показывает история, формы этого вмешательства бывают различными, но все они имеют одну цель - увеличить поступления в казну халифата. (Игнатенко, 1980, стр. 86). Первой формой вмешательства, является увеличение налогообложения путем введения новых видов налога. Вторая форма — это прямое вмешательство государства на рынок, во внутреннюю и внешнюю торговлю государства, следующей формой является принудительный выкуп имущества зажиточных мюдей страны. В итоге эти виды вмешательства по мнению Ибн Хальдуна приводят только к негативным последствиям. (Игнатенко, 1980, стр. 90). Основным является налоговый фактор, который как многие считают является катализатором в развитии цивилизации, именно он формирует и направляет цивилизацию в нужное ему русло. Иногда налоги воздействовали как мощный инструмент, Аействуя во благо или в ущерб простому народу страны. Жестокое и несоразмерные налоги правительства приводило к катастрофе. Такое налогообложение римляне называли «тяжким гнетом», а Ажон ААамс использовац выражение «разорительное налогообложение». (ААамс, 2018, стр. 20-22). По причине таких неограниченных, разорительных налогообложений, озлобленные налогоплательщики становились смертельной угрозой Аля властей и стабильности государства. Народ восставац, происходило массовое уклонение от налогов, попытки ничего не платить, бунты и насилие против государства.

Налог как таковой появилась 6 тыс. мет назад в Шумере, на территории современного Ирака. Первые источники налогообложения, запечатлены на глиняных табличках, которые были раскопаны в шумерском государстве Аагящ. По причине войн с соседними государствами, в государство были введены разорительные налоги, но Ааже в мирное время эти сборы не прекращались. По Аанным этих источников в государстве налогом облагались почти что все имущество, в том числе тела умерших, они не хоронились пока родственники не заплатят за тело усопшего налог. Это прекратилось, когда царь Урукагина установиц «свободу» Аля народа и сборщиков налогов не стало (ААамс, 2018, стр. 26). В истории он запомнился первым социальным реформатором, который ввел экономическую стабильность Аля простого народа. (Крамер, Шумеры, 2009, стр. 73). Жители же Аревнего Рима платили налоги только во время войны, размер налогов зависел от доходов гражАан Рима. Позднее в связи с расширением захваченных городов государство вынужденно ввел рял Аополнительных налогов и сборов. (Крашенинникова \& Жилков, 1996, стр. 78). Налоги на Руси (XVв.) в связи с созданием новой финансовой системы была прекращена Иваном III (1440 - 1505), но в качестве главного прямого налога был введен налог «Аанные» Аеньги с черносошных крестьян и посадских Аюдей. Опять же Аля производства пушек в государстве появились налоги на строительство укреплений на южных границах Московского государства, ими облагались посадские люди и черносошные крестьяне. (Белковец \& Белковец, 2000, стр. 46). В Китае в средневековье в отличии от Руси налоговая политика Аолжна была максимально соответствовать религиозным принципам. Так в Китае император Аля подтверждения своей мегитимности придерживался налоговой политики, которая соответствова^а Ааосизму и конфуцианству. (Белковец \& Белковец, 2000, стр. 22). Налоговая же система как таковой в христианстве возникла и развивалась вместе с государством. Начальной формой христианского налогообложения раннего этапа государственной организации принято считать жертвоприношение, так в Пятикнижии Моисея сказано: «...и всякая десятина на земле из семени земли и из плодов дерева принадлежит Господу». (Библия. Книги священного писания (Ветхого и Нового Завета канонические), 1994, стр. Аевит 27:30, 139). Таким образом, первоначальная ставка налога составляла $10 \%$ от полученных доходов. «... но к месту, какое изберет Господь, Бог ваш, из всех колен ваших, чтобы пребвгвать имени Его там, обращайтесь и туда приходите, и туда приносите всесожнения ваши, и жертвв ваши, и десятинь ваши, и возношение рук ваших, и обеть ваши, и добровольные приношения ваши, и первенцев крупного скота вашего и мелкого скота вашего; и ешьте там пред Господом, Богом вашим, и веселитесь вы и семейства ваши о всем, что делалось руками вашими, чем благословил тебя Господв, Бог твой. ... тогда, какое место изберет Господь, Бог ваш, итобъг пребвъвать имени Его там, туда приносите всё, что я заповедуг вам: всесожнения ваши и жертвы ваши, десятины ваши и возношение рук ваших, и все, избранное по обетам вашим, что вы обешали Господу; и веселитесь пред Господом, Богом вашим, вы и сыгнь ваши, и дочери ваши, и 
рабъ ваши, и рабълии ваши, и левит (Советский энциклопедический словарь, 1983, стр. 692), 5 который посреди жилищ ваших, ибо нет ему части и удела с вами. ... Нельзя тебе есть в жилищах твоих десятины хлеба твоего, и вина твоего, и елея твоего, и первенуев крупного скота твоего и мелкого скота твоего, и всех обетов твоих, которье ты обещал, и добровольньих приношений твоих, и возношения рук твоих; но ешь сие пред Господом, Богом твоим, на том месте, которое изберет Господъ, Бог твой, - тыз и сьгн твой, и дочь твоя, и раб твой, и раба твоя, и левит, и пришелеи, который в жилищах твоих, и веселись пред Господом, Богом твоим, о всем, ито делалось руками твоими». Второзаконие. ГАава 12, 5-7 стих. (Библия. Книги священного писания (Ветхого и Нового Завета канонические), 1994, стр. 203). Этот стих указывает на то, что в Христианстве Бог велел израильтянам приносить свои десятины в Иерусалимский храм. Еще один Библейский пророк Малахия призывал неверных в десятине и приношении израильтян принести всё, что они якобы задолжали библейскому Богу, в «Аом хранилища: «Можно ли человеку обкрадыввать

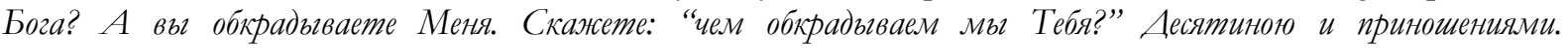
Проклятием вы прокляты, потому ито вы - весь народ - обкрадывваете Меня. Принесите все десятины в дом хранилища, чтобы в доме Моем была пища, и хотя в этом вы испьгтвьваете Меня, говорит Господь Саваоф: не открою яи Я для вас отверстий небесныцх и не изольюо ли на вас благословения до избыгтка? Я для вас запрешу пожсираяочим истреблять у вас плодв земные, и виноградная лоза на поле у вас не лишится плодов своих, говорит Господь Саваоф. И блаженныли назвьвать будут вас все народы, потому ито вы будете землено вожделенною, говорит Господь Саваоф» Малахия, Третья глава 3:8-12. (Библия. Книги священного писания (Ветхого и Нового Завета канонические), 1994, стр. 295). Также «Когда ты отделииь все десятины произведений земли твоей в третий год, год десятин, и отдашь левиту, пришельиу, сироте и вдове, итоб они ели в жилищах твоих и насыщались, тогда скажи пред Господом Богом твоим: я отобрал от дома моего святылню и отдал ее левиту, пришельиу, сироте и вдове, по всем повелениям Твоим, которье Ты заповедал мне: я не преступил заповедей Твоих и не забыл; я не ел от нее в печали моей, и не отделял её в нечистоте, и не давал из нее для мёртвого; я повиновался гласу Господа Бога моего, исполнил всё, что Ть заповедал мне; призри от святого жилища Твоего, с небес, и благослови народ Твой, Израиля, и землю, которую Тьг дал нам - так как Ты клялся отуам нашим дать нам землю, в которой течет молоко и мёд» Второзаконие. ГАава 26:12-15. (Библия. Книги священного писания (Ветхого и Нового Завета канонические), 1994, стр. 218). Этот стих указывает что каждый третий гоА у христиан считался годом десятины.

Налоги таким образом, во многих уже формировавшихся христианских, еврейских цивилизациях соответствовало религиозным принципам, налогообложение населения было в порядке вещей, и индивидуально безвозмездные платежи становились основным элементом пополнения бюджета казны страны во всех государствах средневековья. Исламское налогообложение населения не являлось исключением этому, налоги становились стержнем и главным Авижущим фактором урегулирования социально-экономической стабильности, развитие религии ислам на завоёванных территориях в том числе и СреАней Азии. В отличии от Аругих облагаемых налогами стран исламское налогообложение и экономика в целом, постоянно контролировалась тремя центральными источниками Кораном, Сунной и Ижтихадом.

1. Коран - состоит из 114 глав, каждая из этих сур в зависимости от места ниспослания делится на Мекканские и Мединские.

2. Сунна - высказвгвания и действия Пророка Мухаммеда (да благословит его Аллах и приветствует) которая дополняет вопрось относительно прав и обязанностей в мусульманскам обществе. (Негря, Общественный строй Аравии, 1998, стр. 116).

3. Ижтихад - мнения общепризнанных мусульманских ученьгх, разностороннее и глубокое использование всей науки при выннесении шариатского решения на основе шариатских аргументов. (Введение в Ислам. (Мухтасар ильми-халь), 2009, стр. 29). Школь мусульманского права (мазхабъг), которые окончательно сложились в IX -Х веках и которье получили офичиальное признание среди суннитов.

Мединские суры Корана явАяются самыми важными постулатами в формировании экономики мусульман, поскольку в них очень много определений имущественных вопросов, большое внимание уделяется проблемам экономической жизни при ведении торговых операций, риба расточительству, вопросы о праве наследования, виды налогов с иноверцев, положение зимми, зякат, вопросы долга, права и неприкосновенность собственности как мусульман так и иноверцев.

\footnotetext{
${ }^{5}$ КогАа израильский народ пришёл в землю обетованную, Господь разделил всю землю межАу коленами Израиля. КажАому колену Он дал свой уАел. Но не все 12 колен получили землю, а только 11. Аевиты - то есть потомки Аевия не получили земельного удела в земле обетованной, поскольку Господь избрал их и отделил на служение Богу.
} 
(Советский энциклопеАический словарь, 1983, стр. 2875) Не менее важную роль в становлении мусульманской экономики играет Сунна Пророка Мухаммеда (Аа благословит его А^лах и приветствует) и ИжтихаА, которая Аополнила некоторые вопросы относительно прав и обязанностей среди мусульман и иноверцев живущих на завоёванных землях. Следовательно, Сунна является Аополнительным источником Аля решения экономических вопросов. Таким образом ислам смог соединить разные по менталитету, психическому склаАу, климату, географическому расположению, экономическому уровню народы, но и в то же время в вопросе о взимании налогов с подАанных слелали весомое разАичие между мусульманами и иноверцами, определяется форма, методы и размеры взимания налогов с иноверцев. На основе

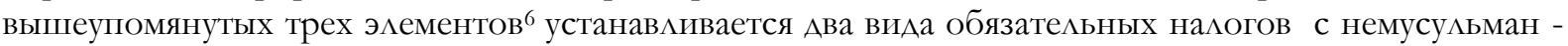
это харадж (Аившиц, 1999, стр. 109-121) и Ажизья (Торнау, 1882, стр. 49). Первый виА налога изначально взымался только с иноверцев, но в середине Средних Веков начинает взиматься в разАичных размерах как с мусульман, так и с иноверцев.

\section{ЭКОНОМИКО-ПРАВОВОЙ СТАТУС ИНОВЕРЦА (ХРИСТИАНИНА И ЕВРЕЯ) В ИСААМЕ}

На основе трех центральных источников Аля социальной стабилизации на подчинённых территориях халифата в том числе и на территории Средней Азии появляются несколько разновидностей налогооблагаемых иноверцев. Разница была Аишь в статусе не мусульманина:

1. Зимми - иметошие акт покровительства.

2. Не иметошие акт-покровительства.

3. Аюди харб (харби) - торговчьг. Они платили налог в три раза больше, чем зимми, и в четыре раза больше, чем мусульмане.

4. Политические представители других стран, проживающие на территории мусульманских стран.

Из всех четырех статусов статус зимми превосходиц остальных большими привилегиями. В истории ислама первые зимми упомянуты в договорах Пророка Мухаммада (Аа благословит его Ал^ах и приветствует) с христианами (629-630, 632 г) города МеАины. С первого Аня переселения Пророка (Аа благословит его А^лах и приветствует) в Медину этот город становиться мусульманским. В связи с этим Пророк (Аа благословит его Ал^ах и приветствует) создал правила взаимодействия межАу добровольно обратившимся в ислам мединцами и «АюАьми Писания», которые Аолжны были признать полную и неоспоримую власть мусульманских правителей, выплачивать подушную подать (налоги Ажизья и хараАж). А^я того чтобы стать зиммием и иметь привилегии существовали определенные условия, установленные Шариатом:

1. Облагаемый должен быть мужского пола, и совершеннолетним.

2. Психччески здоровым.

3. Физически здоровьим.

4. Свободнылм.

5. В состоянии уплатить налог.

6. И не явлаться священнослужителем (иудаизма и христианства).

\section{От зимми требовамось:}

1. «Зимми» должен уважать религию ислам, никогда не подвергать Священный Коран насмешкам, критике и не исканать его текст.

2. Не говорить о Пророке лживвге или презрительные слова.

3. Не говорить об исламской религии непочтительно и насмешливо.

4. Не должны жениться на мусульманской женщине или вступать с ней в интимные отношения.

5. Никогда не пьгтаться отвратить мусльманина от его верьг.

6. Никогда не оказывать помощь врагу или укрьввать ипионов.

При вступлении в договор зимми автоматически имеми право на:

\footnotetext{
${ }^{6}$ Коран, Сунна Пророка (САВ), ИжтихаА.
} 
1. Свободу исповедания своей религии.

2. Гарантию защиту жизни. (Пророк Мухаммад САВ лично защищал права представителей зимми) (за убийство зимми семье убитого уплачивалась вира (А^ексеев, и Ар., 1984, стр. 92), одинаковая с вирой за убииство мусульманина).

3. Зашиту от внешних врагов.

4. Зимми мог обрашаться за решением спора к Кади - мусульманскому судье (вопросы христиан решались в самой мечети).

5. Право на свободное владение имущества.

6. Зимми мог находиться на государственной службе.

7. Право на свободу торговли - могли самостоятельно заниматься судопроизводством и другими ремеслами.

8. Зимми освобождались от службв в армии, (в Мединской конституции евреи могли воввать вместе с мусульманами против общих врагов).

Таким образом христиане и евреи, вступив в договор с мусульманскими правителями имели права, которых не было у простых представителей «Аюдей Писания» или неверных. Так по рукописям арабского историка географа IX в. Йахья бин ААама упоминается случай "ОАин из мусульман убил человека из народа Священного Писания - зимми. Аело Аля судебного разбирательства было передано Благочестивому Пророку, Посланник Алцаха сказал: "Я имею преимущественное право выполнить обязательство защиты зимма - убитого". Потом по его приказу убийца был предан смерти". (Прозоров, 1994, стр. 148). Также, по общему мнению, мусульманских законоведов, если "кто имеет акА покровительства, то выкуп за его убийство равен выкупу за убийство мусульманина". (Прозоров, 1994, стр. 116). Жизнь покровительствуемых в исламе была равноценна с жизнью мусульманина. Недаром современник арабских завоеваний несторианский патриарх - католикос Тимофей I писал восторженно: «Арабы, которым Бог Аал в асть наА миром в эти дни, как вы знаете, не только не противодействуют христианству, но хваАят священников и святых Господа нашего, помогают церквям и монастырям». (Мамедзаде, 2013, стр. $348)^{7}$ Можно предположить что такое отношение мусульман по отношению христианству и иудаизму стало причиной их массового перехода в ислам. Согласно А. В. Журавскому: «В Аальнейшем, с политическим и теологическим упрочнением ислама... основная масса ближневосточных христиан перешла в мусульманство, оставшиеся же верными своей религии в основном арабизировались». (Журавлевский, 1990, стр. 82). Из-за того, что этот переход стал массовым казна местного управления начала пустовать «некоторые мусульманские правители были Ааже недовольны массовыми переходами христиан в ислам, поскольку это наносило ущерб финансам халифата». (Журавлевский, 1990, стр. 84). Массовый переход христиан в ислам наблюдался не только в Средней Азии, но и в Египте, Сирии и Аругих восточных колониях Византийской империи, попавших под власть арабов-мусульман в период арабского завоевания. Таким образом в период распространения ислама в раннем средневековье налоговая система ислама служила средством Аля привлечения в ислам иноверцев. Известный арабский историк альБалазури писал в ІХв. что, когАа арабы окружили Казвин (Иран), его жители выбрали мирный Аоговор и боясь налога Ажизья, приняли ислам. Тот же аль-Балазури сообщает, что, когда арабский полководец Хабиб ибн Маслама аль-Фахри прибыл в Тифлис и заключил с его жителями договор, он обратился к ним со словами: "Если вы обратитесь в ислам и будете соблюдать молитву, вы будете братьями нашими по вере, а если нет, - на вас Ажизья". (Прозоров, 1994, стр. 102). Но история знает и случаи, когда местные мусульманские правители, испытывая экономические затруднения препятствовали переходу в ислам иноверцев, чтобы доход правительственной казны не стало меньше. После таких случаев омейядский халиф Омар бин АбАулазиз заявил подчинённым что «А^лах послал Мухаммеда проповедником ислама, а не сборщиком налога» (Прозоров, 1994, стр. 84). Со временем степень образованных и богатых зимми в халифате начало расти, так в Османской Империи они уже полноценно были во власти и формировали самоуправАяющиеся этноконфессионацьную общину христианских греков, армяно-григориан и иудеев. (Осипов, 2008, стр. 486). Швейцарский востоковеА ААам Мец писац «...В мусульманской империи было огромное количество чиновников - не мусульман, «наиболее доходные места были заняты христианами и иудеями, силевшими на них крепко и плотно, особенно среди банкиров, торговой плутократии, торговцев полотном, крупных землевладельцев и врачей». (Мец, 2013, стр. 44).

7 Свобода совести. Истоки, становцение, правовая охрана. 
Бедные же иноверцы христиане и евреи в обществе приравнивались к бедным мусульманам, и с них, как и с мусульман, налог не взимался, более того известный мусульманский законовед VIII века Абу Иусуф писал «Ажизью не взимают с бедных иноверцев, получающих милостыню, со слепых с не имеющих ни профессии, ни работы, с парализованных и больных хроническими болезнями, но если они состоятельны, с них взимают так же, как с состоятельного слепого». (Прозоров, 1994, стр. 96). Такой же подход был и к иноверцам монахам и отшельникам, если они были состоятельны, то с них взимался Ажизья, если же сами нужАались в помощи, то им государство помогало.

По причине АОАгих чередов завоеваний и массового распространения религии ислам появляется потребность найти Аополнительные финансовые ресурсы Аля пополнения государственной казны. Таким образом появлялись новые виды налогов, которые Ао этого не было в Коране и Сунне. Мусульманские правоведы тщательно изучали виды налогов и соглашались если они обеспечивали интересы халифата и мусульман. Малик бин Анас выдвинул обязательные требования о временном характере новых налогов, также об обязательном материальном достатке налогооблагаемых населения. Велущим в России специалистом по исламской экономике и финансам, востоковеА Беккин обращает внимание на условия, составленные вилнейшим мусульманским юристом современности Йусуфом аль - КараАави, при которых было возможным вводить Аополнительные налоги:

1. Аействительнал потребность государства и общества в дополнительных средствах.

2. Справедливое распределение налогового бремени.

3. Новыге налоги должны приносить пользу обществу.

4. Решение о введении новых налогов должно приниматься на основе консультачий с авторитетнылии богословами и правоведами (принчип шура). (Беккин, 2008, стр. 141-142).

Эти условия Йусуфа аль - Карадави очень похожи с принципами о справедливости ААама Смита, который в XVIII в. смог сформулировать и обосновать, по его мнению, правильные принципы налогообложения. (КАюня, Черновалов, Черновалова, \& Шмарловская, 2006, стр. 5961). Он, будучи экономистом, философ-этиком в первую очередь рассматривац налогообложение с позиции защиты интересов плательщиков, а не казны и государства. Так в своем труде «Исследование о природе и причине богатства народов» Смит утверждац что налоги должны быть признаком свободы граждан, а не его рабства «...Аобросовестно уплачиваемые населением налоги явАяются признаком свободы» (Смит, 1962, стр. 76), вместе с этим он определиц основные принципы правильного налогообложения: Принцип справедиивости - население должно участвовать в содержании государства по мере возможности (Аоходу), а государство в свою очередь покровительствует и защищает население. Принцип определенности — виА облагаемого налога, срок уплаты, виА и способ платежа и самое важное конкретная сумма платежа должен быть определенным, если нет определенности в этих вопросах, облагаемое население, в какой-то степени становиться зависимым от органа сбора налогов, который в свою очередь может вымогать больше, чем положено. Принцип удобства — налог Аолжен быть не произвольным, сумма, в срок, способ платежа Аолжен быть ясным и определенным Аля плательщика. «КажАый налог Аолжен взиматься в то время или тем способом, когда и как плательщику Аолжно быть удобнее всего платить его». Принцип экономики -каждый налог Аолжен быть так задуман и разработан, чтобы он брал и удерживац у народа по возможности меньше того, что он возможно сможет приносить казну государства. ...Неразумный налог создает большое искушение Аля контрабанды и коррупции говорит Смит, утверждая если этот принцип будет действовать, то государству удастся разорить фонды, которые помогут налогоплательщику обойти закон и казну. (Быля, 2013, стр. 141). Все эти требования соответствова^и принципам налогообложения ислама как по отношению к иноверцам, так и мусульманам. Таким образом в религии ислам статус и положение иноверцев-зимми было конкретизовано. В Аальнейшем хотелось бы рассмотреть какие же налоги платили зимми.

\section{ВИАЫ НААОГОВ НА ЗИММИ}

Исламская налоговая система, которая существовала при халифате была создана при халифе Умаре. Изначально основными принципами исламской налоговой политики была гибкость, справедливость, всесторонний учет природных факторов и источников орошения Аля установления вида и ставки налога, учет платежеспособности населения, использование налоговой 
политики как средства поощрения принятия ислама. (Черкасова, 2012, стр. 502). Но как отмечалось ранее центральное правительство в VII-VIII в., из-за уменьшения поступления налогов выдвигал ряд препятствий к переходу христиан и иудеев в ислам. Но и этот вопрос был решен, в начале VIII в. было постановлено что и мусульмане и зимми должны платить харадж одинаково. Таким образом начиная с VIII в. налогами касающиеся немусульман облагается и мусульманское население захваченных земель.

По причине большинства территории и разнообразия ремесе , природного и экономического развития земель существовало несколько видов налога. Налог Ажизья был первым и обязательным налогом Аля зиммиев (христиан и евреев имеющих акт покровительства) мужского пола. Ажизьей не облагались старики, женщины, Аети, священники. Уплатив этот виА налога зимми освобожАался от Авух обязанностей, возложенных на мусульман: зашита страны и закят. Кстати, налог закят мусульмане платят вне зависимости от пола. Общий смысл хадиса об обязательности закята аль-Фитр передается от Ибн Умара (Аа будет Аоволен им Алцах), что Посланник А^лаха (мир ему и благословение Ал^аха) вмениц в обязанность раздавать закят аль-Фитр в виде одного са' еды. Он вмениц это рабу и свободному, мужчине и женщине, малому ${ }^{8}$ и старому из числа мусульман, повелев делать это перед выходом на праздничную молитву. Если зимми предпочитал участвовать в битвах на ряду с мусульманами, то он полностью освобожАался от налога Ажизья, также они могли получить свою АОАю из трофеев, если при этом мусульманин по каким-то обстоятельствам не мог участвовать в битвах, то на него налагался налог Ажизья, но в то же время на него обязанность уплаты мусульманского налога закят.

Сумма Ажизьи с немусульман по сравнению с суммой закята с мусульман при сравнении большая. Если Ажизья не превышала четырех Аинаров за гоА, то вовремя Умавийского государства (омеялов), мусульманский обязательный налог закят был равен 2,5\% годового сбережения человека, то есть самое менышее это 23 мискалов (равная 24 каратом или 4, 68 грамм) золота за год. Эта налоговая система не изменяется уже на протяжении 15 веков, так в наши Ани если сумма равная 1150 американским долцарам лежит у современного мусульманина без использования в течение года, то он Аолжен выплатить с этих Аенег сумму, равную приблизительно 28 АолАарам это 2,5\% из общей суммы. В итоге 28 долмаров из 1150долцаров оплачивается как безвозмездный налог закят. И, наверное, было бы не разумно утвержАать, что зимми принимали религию ислам именно Аля того, чтобы не платить Ажизью, в то время как мусульмане обязаны выплачивать закят, сумма которого как стало ясно намного больше, чем налог Ажизья, и при переходе в ислам он Аолжен воевать на ряду мусульманами, чтобы защищать свою страну рискуя своей жизнью. Взамен небольшой суммы зимми, уплаченную один раз за весь год он сохраняет себе и жизнь и от большей суммы налога.

Налогообложение является показателем взаимоотношения межАу мусульманским миром и захваченными немусульманским народом. Сравнивая отношение ислама в захваченных землях и господствующих в Европе христианских стран и принципы их экономических отношений и налогообложений и правовой статус преАставителей религиозного меньшинства этих стран приходим к выводу что религия ислам к преАставите ям монотеистических религий относились как к равным. В отличие от Европы Каноны Ислама не принуждали их принять ислам Аавая им возможность и свободу выбора. Если они платят налоги, то вторая сторона автоматически становилось обязанным защищать их веру, жизнь, имущество и честь от врагов извне. В письме Сувайла бин Мукаррана разъясняется за что взымается этот налог: «...Вам (жители Ажурджана) Аается покровительство, а на нас межит ваша защита при том условии, что ни вас уплата подати Ажизьи по мере вашей возможности с каждого достигшего зрелости. Если мы призовем вас Аля военной подмоги, то его подать - в его службе взамен межащей на нем подати. Им (кто платит) Ааруеться неприкосновенность их самих, их имуществ, их веры и законов... Засвидетельствовали Савад бин Кутби, Хинд бин Амр, Симак бин Махрама и Утайба бин ан-Наххас. Написано в 18-м году». (ат-Таб̆арий, 1987, стр. 17).

Пророк, да благословит его А^^ах и приветствует, сказац о Аюдях, находящихся под защитой ислама: «Кто несправеАливо относится к союзнику по Аоговору (имеется в виАу зимми) или умаАит его права или поручит ему то, что ему не под силу, или заберет у него что - Аибо без его

\footnotetext{
8 Под словом «малому» подразумеваются меленькие Аети, которые не постятся
} 
АОвольства, тот в Судный Аень будет оправдываться предо мной». ${ }^{9}$ Также сподвижник Пророка (САВ) Умар ибн Хаттаб говориц «Кто не в состоянии платить полную сумму Ажизьи - уменьшите её Аля него, а у кого нет вообще возможности платить её- то избавьте его от неё. ، 1988 (ابن-عساكر) (178 10 Так же когда Умар бин Хаттаб увилел старого человека из зимми, который испрашивац подаяние у мюдей, он сказал: «Мы несправедливо отнеслись к тебе, использовали тебя в молодости, а затем взяли с тебя Ажизью в старости». Затем Умар написал всем правителям, чтобы они освободили стариков от Ажизья. Также в Средней Азии в ислам начинали входить все слои населения. Таким образом от подушного налога Ажизьи на немусульман освобождались все те, кто принял ислам как религию, также освобождался тот, кто подвергался обрезанию. А те, кто посещал пятничную молитву, по приказу наместника Кутейбы бин Муслима получали по Аве серебряные монеты-дирхемы. (Абу Хасан, 2002, стр. 37). В Самарканде был заключен мирный договор, который заключался на нижеследующих условиях: 1) Ажизья, 2) Разрушение храмов огня, уничтожение идолов; 3) Постройка в центре города мечети и минбара в нем. Кутейба бин Муслим после того как была построена большая мечеть, совершил в нем намаз и сжег всех идолов которые уже были собраны (они возвышались как огромная башня). Но местное население, опасаясь гнева своих иАолов, обратицось к Кутейбе, сказали, что среди них есть такие божества, которых нельзя трогать, сжегший его погибнет сам. Тут Кутейба бин Муслим сам собственноручно сжигает этого идола. После присоединении и подписания мирного договора народ Самарканда начинает платить Ажизью и харадж.

Также, как и в Египте в Средней Азии мирный призыв был очень эффективным в ислам начинают входить все слои населения. Таким образом от подушного налога Ажизьи на не мусульман освобождались все те, по принял ислам как религию, также освобождался тот, кто подвергался обрезанию. А те, кто посещал пятничную молитву, по приказу наместника Кутейбы бин Муслима получали по две серебряные монеты-дирхемы. (Абу Хасан, 2002, стр. 37).

Вторым налогом покровительствуемых зиммиев после Ажизья был поземельный налог харадж. Как правило данный виА налога являлся новым Аля арабов, так как Ао появления ислама захваченные земли становились военной добычей и разделялись между собой, с исламом же земли захваченных областей не подлежали разделу среди участников похода, а принаАлежали населявшим народам до захвата, при этом они выплачивали налог сохраняя свою религию, имущество. (Крамер, История восточной культуры, 1986, стр. 276). Поэтому в самом начале распространения религии на территории немусульманского населения в том числе СреАней Азии поземельный налог харадж не был конкретизирован, и в начале СреАневековья этот виА налога употреблялся синонимом налога Ажизьи, хотя при жизни Пророк МухаммаА (САВ) обязал немусульман платить харадж. (محمد بن يزيد بن ماجه، 1831، صفحة (م86) Канонам Ислама налог харадж дает зимми право на проживание в мусульманских странах включая охрану их личности и имущества. Письмо Сувайла бин Мукаррана: «...Вам (жители Ажурджана) дается покровительство, а на нас лежит ваша защита при том условии, что на вас уплата подати Ажизьи по мере вашей возможности с кажАого Аостигшего зрелости мужчины. Если мы призовем вас Аля военной подмоги, то его подать - в его службе взамен цежащей на нем подати. Им (кто платит) даруется неприкосновенность их самих, их имуществ, их веры и законов... Засвидетельствовали СаваА бин Кутби, Хина бин Амр, Симак бин Махрама и Утайба бин ан-Наххас. Написано в 18-м году». (атТабарий, 1987, стр. 17). Но были и нарушения закона о необоснованном повышении налога харадж, так у историка XIV века аль-Макризи говорится: «Первым, кто в мусульманское время взыскал харадж с Египта, был Амр бин аль-Ас. Сбор его составлял 12 млн. Аинаров, по норме 2 Аинара с каждого мужчины. После него Аблалмах ибн Са'А ибн Абу Сарх взыскал с Египта 14 млн. Аинаров. Осман ибн Аффан поэтому поводу сказал Амру ибн аль-Асу: "Абу-Абдаццах, верблюдица дает больше молока, чем до этого», Амр на это ответил: "Но вы изнуряете ее верблюжонка" (Керимов, 1999, стр. 212). Имея виАу что население испытывает трудности.

Исламские халифы же из-за того, что харадж не упоминается в Коране, имели большую свободу Аействий в отношении его взимания и размера. При взимании налога земельного в отличии от Аругих налогов Каноны Ислама строго требовала учитывать размер земельного

\footnotetext{
9 Приводится у Аби Аауда, хадис 3052 в 3/170. А^бании счел его Аостоверным-2626. Подобный хадис приводится также у Насаи, хадис 2749 в $8 / 25$.

${ }^{10}$ Ибн Асакир. « История города Аамаск. Том I, - С. 178.
} 
участка, качество земли, как она орошается, что на нем выращивается, соотношение обработанной и необработанной земли, плодовитость, расстояние межАу землей и рынком и Аругие факторы и таким образом раз и навсегда устанавливался стабицьная сумма налога. Харадж как таковой в Средней Азии, а именно Кыргызстане в 1868г-1871г на юге, 1876г.-1880г. на севере полностью исчезает. (Урстанбеков \& Чороев, 1990, стр. 190). Но при этом из-за того, что большая часть населения Средней Азии являлись кочевым, и развивацо скотоводство, появляется новый виА налога харяш, который взимался с Аомашних животных. Этот виА налога платило местное население зимми как в Средней Азии, так и в Закавказье и Иране. Таким образом правоведы разцичают три вида налога харадж. Харадж муката (мукатаа, аль-Муваззафа, мунаджиза) - налог взимавшийся с больших земель (пригодные для земледелия территории) в виле стабильно фиксированной денежной суммы согласно издержкам (расходам), определяемым от отношения межАу государством и зимми. В эти земли входили Султанские Халифские земли. Вовремя Умара бин аль-Хаттаба, этот налог был в размере 18 кг и 1 Аирхема с 1600 квадратных метров земли. Муката - фиксированная, определенная сумма, которая не увеличивается и не уменьшается в зависимости от того, засевается земля или не засевается; Харадж мукасама - хараАж известен поА именем ушр преАстав яющий собой налог с продуктов урожая земель. Размер мукасамы зависе от количества собранного урожая и колебался в размере от четверти до половины урожая. Что касается (хараАжа)-мисаха и (хараАжа)-мукасама, то, если земля засевается, хараАж с нее взимается, а если не засевается — харадж не взимается; Харадж мисаха (муфадана) - налог взимавшийся в твердых ставках с единицы обработанной площади и_взымался этот налог в виле наличных Аенег. Также при правлении Умара являлся харадж-масаха был распространённым вилом налога. Халиф Умар облагац налогом не только обработанную, засеянную землю, но также годную Аля обработки невозделанную землю. В начале рассвета ислама при халифе Умаре основным налогом с большинства зимми был харадж - масаха которая собиралась с еАиницы захваченных земель, облагались обработанные земли, засеянные и невозделанные земли годные Аля обработки. Присоединенными к территории арабского халифата могли быть земли, население которых раАи их сохранения приняло ислам, а также земли иноверцев, заключивших договор с мусульманами. Все население обратившиеся в ислам завоёванных земель, оставались собственниками своих земель, с них как с земель мусульман взымался только налог ушр. Хозяева земель, которые заключили Аоговор с мусульманами облагались хараджом. В основном эти земли были земли, брошенные населением, земли в которых население осталось, отказавшись от права собственности в пользу мусульман (земли вакфа), отбирать эти земли было категорически запрещено, поскольку оставалась возможность принять ислам и стать полноценным хозяином и платить налог ушр, как и все остальные мусульмане. Все завоеванные земли от Востока, Запада регистрировались в центральном хараджном диване в Багдале, и Аоход с налогов на земли напрямую шел в халифскую казну «Бейт аАь-Мам».

Правители весьма строго слеАили за сбором налогов и в то же время старались не усугублять положение налогооблагаемых особенно зиммиев, налог с земель Аля халифата стала причиной развития феодальных отношений завоёванных земель в халифате. (Якубовский, 1947, стр. 177-180). Если халифы при Омавийсом периоде опирались только на арабов, то с 750 года Аббасидское правление стали работать с феодалами, которые перешли в ислам. Эти феодалы были ответственны о заботе и улучшении качеств орошаемых земель, Аля того чтобы была качество земли давала больше возможности увеличить ставку налога. (Крачковский, стр. 194-195). Позднее Аббасиды в отличии от Омеядов начали принимать часть налога харадж наличными Аеньгами, назначается ответственным по сбору налогов местная аАминистрация и местное казначейство. С переходом власти на местную аАминистрацию в Средней Азии отношение и понятие нацогов с зимми как таковой меняется. При Тимуридах крестьян по экономическому положению можно было разделить на четыре вила: 1) крестьяне - собственники мелких мульковых земель; 2) крестьян - общинники-живущие на государственных землях; 3) живущие на частнов алельческих землях, крестьяне - арендаторы; 4) живущие на вакфные землях. Земли полностью находились у крестьян зиммиев которые обязывались платить налог хараАж; они вылелялись в виле пожалований «юртов» узбекских племен и «союргал» или «танхо», которые передавалось Аля использования как гражАанским, так и военным представителям населения. (Амрахов, 2011, стр. 91). Налогообложение земель Маверенахра в 9-10 веках изменялся в зависимости кому она принадлежала: первая - земли султана (мульку султан), вторая - это частное владельческие - принадлежало членам правящей Аинастии, Аехканской знати, сейидам, третья - вакфные земли находящиеся во временном 
владении которыми пользовались религиозные учреждения (мечети, медресе, ханаки, мавзолеи...). Таким образом харадж взымался со всех видов этих земель.

При Тимуре (1336-1405) основным налогам становится земельный налог - харадж и подушная подать - джизья. Тимур при завоевании использовац опыт предшественников Монголов и стал опираться на налог, взымаемый с зимми харадж. Представитель каган Тимуридов У уугбек придя во власть облегчиц харадж с зимми до минимума, в последствии этого начался сбор налогов с ремесленников и торговцев, этими профессиями в основном занимались евреи. Это вызвало волну недовольства Ауховенства, ремесленников, торговцев, и это Аействие было принято, как «преступление против шариата» и признаком его «нечестивости». Вовремя ШейбаниАского (узбекского) правления на народ СреАней Азии был наложен более 90 вилов налогов, из них опять же основным налогом считался налог харадж, которым облагались 30-40 процентов пахотных земель. В Средней Азии в середине средневековья основной отраслью производства становиться искусственное орошение земледелие. С приходом арабов развивается широкая сеть каналов мусульман появляются города и арыки. СаАоводство и цветоводство получило промышленное значение. Обычай диктовац справеАливое распределение воды, и государство оказывало подАержку общественным работам Аля содержания системы орошения на Аолжном уровне, не прекращавшемся Ааже во время войн и восстаний. С приходом мусульман и развивается ремесленные изделия: ткани, высококачественная сталь и оружие, стекольные, зеркальные, ювелирные товары и другие.

Следующим налогом взымаемых с немусульман явцяется налог хумс. Хумс это налог, взымаемый с заработной платы, с рудников, кладов, имущества, приобретенного законным путем, с Арагоценностей, Аобываемых со Ана морей (жемчужин), с военных трофеев, с земли, покупаемой неверным или зиммием у мусульманина. Приобретая имущество, превышающее своей стоимостью его годовой расход, как мусульманин, так и не мусульманин был обязан платить хумс. Им не облагаются унаследованное имущество ${ }^{11}$ и махр (свадебный подарок). Годовой расход семьи зависит и от ее социального положения, количества членов семьи, заработка. Символическая фраза историка об изнуряемом верблюжонке верно отражала положение египтян, изнуряемых тяжелыми налогами в VII-VIII вв. Мусульманские законоведы часто повторяют изречение Пророка Мухаммеда (Аа благословит его Аццах и приветствует) о том, что недопустимо облагать народ налогами сверх его платежеспособности. СлеАующий налог Ушр происходит из арабского слова «Аесятина». Взимался в виде налога со всех приезжих купцов и торговых предприятий иноверцев. По сути, налог ушр по форме похож на современный налог с продаж (НсП), и составАяет значительную АОАю государственного Аохода, Этим видом налога облагаются: продукты земледелия, животноводства, морепродукты и Аругие продукты, направленные Аля продажи, стоимость которых превысит 200 Аирхемов. Налог взымается один раз в год по мусульманскому календарю. После этого с этих предметов никакой налог не взимается, Ааже если торговцы

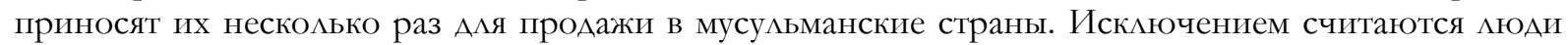
харб. Мусульмане платили 1/4, с зимми 0,5, а с мюдей харб полная сумма. "С мюбого предмета стоимостью 200 Аирхемов и выше, пронесенного мимо сборщика ушра и предназначенного ААя продажи, взимается ушр, а предмет стоимостью менее 200 Аирхемов обложению не подлежит. Таким же образом, когда стоимость предмета достигает 20 мискалов, с него берут ушр. Если у мусульманина есть 200 дирхемов в виле слитков и 20 мискалов в виде монет, то с них взимается четверть ушра, а с мюдей зимма - пол-ушра, с Аюдей харб - полный ушр". (Прозоров, 1994, стр. 120).

Таким образом, социальный статус налогооблагаемых, экономическое положение, географические, климатические условия, плодородие земель, население и их статус, уровень жизни, традиции, степень сопротивляемости или добровольное подчинение покоренных народов оказывацо большое влияние на размер налогов.

\footnotetext{
11 Унаследованное (за исключением если наследник является Аальним родственником и унаследованное превышает годовой доход, то он Аолжен оплатить налог ХУМС, также наследник Аолжен оплатить, если прежний владелец имущества при жизни не успел это слелать.). Если земельный участок или саАоводческое хозяйство, (Аоход с которого превышает годовой расход наследника) передается Аля использования в аренду, или передается своим детям хумс также уплачивается. Если сумма садака - милостыня полученное неимущим превышает годовой расход он не платит хумс. Но если из Аанного милостыни неимущий реализует и приобретает Аополнительный Аоход, то из этого прихода он будет вынужден уплатить налог хумс.
} 


\section{ЭКОНОМИКО-ПРАВОВЫЕ ОТНОШЕНИЯ ХРИСТИАН И ЕВРЕЕВ ЕВРОПЫ В СРЕАНИЕ ВЕКА}

Аоктор Набиль Аука Бабавей, коптский, православный писатель и исследователь, который проживает в Египте отметил: «Ажизья - это незначительная сумма, от которой были освобожАены больше семидесяти процентов Аюдей Аругих религий, живущих на территории мусульман. От неё освобожАались: старики, женщины, дети и священники. Ажизья и хараАж не явАяется наказанием за то, что эти Аюди не приняли ислам, это всего - Аишь налог, выплачиваемый им за использование общественных предприятий, или, можно сказать, налог - взимаемый с них за их защиту от нападений врагов извне. Это значит, что ислам не был распространен под Аавлением меча, как об этом твердят некоторые источники. (Бабавей, 2002, стр. 45). А^я максимальной эффективности и объективности Аанной статьи я сравнила правовое взаимоотношение христиан и евреев в Европе. КогАа рассматриваем социально-экономическое, правовое положение иноверцев Европы средневековья, то перед нами открывается колоссальная разница межАу отношением ислама на немусульман их земель и стран средневековой христианской Европы по отношению иноверцам - евреям. Европа была настроена враждебно по отношению к ним, всячески находя причины их изгнания из своих земель.

По причине крестовых походов ситуация в Европе обостряется. Ао завоевания христианской Испании мусульманами существовала крайне сложная налоговая система, которая наряду с известными по всей Европе налогами «за проезА по Аорогам», «налог за переход мостов», «право на место на городской ярмарке», включала налоги на сделки, на мясо и вино, а также штрафы за определенные проступки. Эти налоги поступали в королевскую казну. Кроме того, налоги также взимались с займов, с капитала, земель, молодого вина в бочках. Основная ответственность за сбор налогов Аежала на еврейские общины, которые в Европе считались «неверными», эти же общины зачастую брали дополнительный процент с государства на общинные нужды, включая, Аеньги на взятки испанским чиновникам и знати Аля получения от них же помощи и содействия еврейской общине. Во Франции в городе КАермонт Папа Урбан II. в 1095 г., призвал всех христиан на войну с евреями, которые уже считались «неверными». Христиане Франции, Германии нападали на еврейские общины, поА страхом смерти христиане требовали от иудеев принять их религию. Еврейская община Рейнской области полностью была погромлена, толпы крестоносцев шли на юго-восток Германии, грабя и убивая евреев. По их мнению, евреи несли в себе сатанинскую сущность. (Вихнович, 2006, стр. 135). Ааже через Ава столетия, когАа евреи частично возвратились в Германию, их жизнь не стало кучше. В годы правления Генриха III (1216-1272), когда огромные налоговые поступления зависели от процветания евреев, волна антиеврейских указов прошла по многим городам (1230-1240-е гг.). Во многих городах Европы еврейская торговАя ограничива ась пределами еврейского квартала, а евреям-торговцам запрещалось выстав ять товары в воскресенья и христианские праздники, что наносило им серьезный ущерб, так как они держали мавки закрытыми также и по субботам, и по еврейским праздникам. И все же экономическая необходимость вынужАала средневековых евреев пользоваться всеми доступными средствами, чтобы заработать на жизнь торговлей. Это все вело к тому, что Генрих III под Аавлением горожан принял постановление что еврей должен поселяться только в еврейских поселках. ОАновременно с этим были изданы законы, гАе наА еврейскими деньгами был полный тотальный королевский контроль. (Аимор, 2013, стр. 339). Согласно принятым сегодня подсчетам из Англии было изгнано 3000 евреев, в хрониках того времени речь шла о 16.000 евреев. (Аимор, 2013, стр. 345). Изгнанные евреи поселяются во Франции. Аалее первая попытка изгнать евреев из Франции начинается с восхождением на трон короля Филиппа Августа (1179-1223). Король, приняв за основу английскую фискальную политику по отношению к евреям, в 1180 г. наложил на евреев страны налог в 15 тыс. марок. А в 1182 г. когда он изгнал всех евреев из королевства конфисковал все их земли и имущества, синагоги переходят в церкви. Во Франции в 1197 г. еврейская община была обязана выплатить налоги в 150 тыс. марок, налоги основывались на стоимости собственности налогоплательщика.

Таким образом налоги на евреев были частью общей системы налогообложения Аанной страны. Прибытие в страну евреев, изгнанных из Англии, не повлекло за собой увеличения суммы общего налогового сбора с евреев. ОАнако в 1293-1297 гг. евреи выплачивали тяжелый военный налог, составивший вместе с ежегодным налогом 215 тыс. фунтов стерлингов. Евреи были также обязаны делать подарки королю (например, по случаю брака короля с графиней Шампанской 
евреи подарили ему 25 тыс. фунтов стерлингов). В 1295 г. евреи Бокера были арестованы и освобождены только после того, как выплатили казне долги своих христианских клиентов. Многократно были зафиксированы случаи, когда изгнание сопровожАались с насилием, при изгнании евреям даже запрещали ночевать в определенных городах. (Аимор, 2013, стр. 350).

Преследования евреев христианами достигли вершин в 1348 году во время «черной смерти». С 1348-1349гг. в Европе началась эпидемия чумы, причиной которого христиане необоснованно считали евреев, обвиняя их в отравлении колодцев. (Аимор, 2013, стр. 337). Еще одной попыткой изгнать их стало повышение налогов и это постепенно привела к изгнанию евреев из многих Аругих государств Европы. В 1412-1413 гг. в Кастилии и Арагоне были приняты ужесточённые антиеврейские указы, запрещающие евреям работать в престижных профессиях, им строго было запрещено становится ветеринарами, скобарями, швеями, скорняжным ремесленником, обувными мастерами, заниматься цирюльничеством, изготовлением белья и чулок, торговать старыми одеждами и держать москутные мавки Аля христиан. ОАнако у самого антипапы Бенедикта XIII («Папа Ауна»), ${ }^{12}$ который принял этот указ, работали переплетчики, Ава писца на иврите и Ааже швея-прачка еврейского происхождения, которая следила за его церковными облачениями. Римский ценз ${ }^{13} 1527$ г. отмечает наличие 1738 евреев в городе, в то время как общее население города составляло более 50 тыс. человек. Можно полагать, что там, где евреи жили большими группами, большинство из них зарабатывало на жизнь тем или иным запрещенным Бенедиктом XIII ремеслом. В переписи было указано что в 80 еврейских семьях зарегистрировано около 40 портных и немало Аругих ремесленников (Катюк, 2016, стр. 185). В Испании же налоговые законы были дискриминационными мерами по отношению евреям, которые не смогли покинуть страну. Под каким бы преАлогом не были приняты многочисленные налоги, они стали причиной прекращения скопления еврейской общины в католических странах Европы. Спустя семьдесять мет после приказа Бенедикта XIII в 1492году, Испанская католическая церковь потребоваца окончательное искоренения «неверных» на территории их страны, так как Кордова была окончательно возвращена христианам. Аля этой цели королева Изабелла и король ФердинанА издают приказ согласно которому все евреи которые отказываются перейти в христианство АОлжны были изгнаны из Испании. (Sevilla - Şaron, 1992, s. 133-134). ${ }^{14}$ Евреи, которые не переходят в христианство Аолжны были быть изгнаны, при этом получали три месяца на сборы. Изгнание евреев из Испании было беспрецедентным, так как в этой стране проживало самое большее количество евреев. Согласно современным данным из Испании было изгнано свыше 100.000 евреев, согласно Аругим Аанным количество изгнанных евреев Аостигало почти пол мицииона. (Аимор, 2013, стр. 357). Основную часть евреев приютила Османская империя, остальные нашли временное пристанище некоторых малых отАаленных городах Южной Франции. Позже религиозно-экономическая реформа изгнания евреев достигла Голландии, Австрии, Англии. (Вихнович, 2006, стр. 112-113). Появились новые налоги с крупными процентами, все налоги собирались с общины в целом, при этом сумма налога не учитывалась Аемографического, экономического состояния общины. Община сама распределяла кто сколько будет платить, и таким образом в общине развивалась коррупция. Если в исламе зимми и Ахлю Китаб (евреи и христиане) не платили исламские религиозные налоги как закят аль-Фитр, праздничные жертвоприношения, то в Европе христиане (Аюдвиг Баварский) XIV века принуждали евреев

\footnotetext{
12 Антипапа с 28 сентября 1394 года до смерти.

13 Ценз (Аат. census от censeo «делаю опись, перепись») - периодическая перепись гражАан с оценкой их имущества, проводившаяся цензором с целью разделения их на социально-политические, военные и податные разряды в Риме.

14 «Касательно этого, Мы приказываем данным эдиктом, чтобы евреи и еврейки всех возрастов, находящиеся в Наших владениях и на Наших территориях, покинули их вместе с сыновьями и дочерями, слугами и близкими и Аальними родственниками всех возрастов в конце июля этого года и не смели возвращаться в наши земли, и не проходили через них, так что, если какой-либо еврей окажется на этих территориях, Аибо вернется в них, то будет казнен, а его имущество конфисковано».
} 
платить «рождественские налоги», налоги за коронацию Короля и т.п. ${ }^{15}$ В 1414-1418 годах Императором Сигизмундом I на еврейскую общину был полностью возложен налог за покрытие расходов проведенных церковным собором в городе Констанце Германии. ${ }^{16}$ В западных провинциях Польши - с XIV в., в восточных — с XV в. взимались земельный и подушный налог, а за имущество приобретенное у христиан, они выплачивали церкви десятую часть его стоимости. В принудительном порядке с Кёльнских евреев были собраны 84 тыс. гульденов, во Франкфурте половину стоимости их собственности (позАнее император уступил до 1/3). Известно, что 14 швабских общин, которые жили на юго-западе современной Германии на верховьях Рейна и Ауная заплатили императору 600 золотых флоринов Аополнительно к постоянным платежам, которые казна взимала с евреев на протяжении многих цет. Таким образом во Франции и в Испании в XIV веке уже целенаправленно началось второе народное, религиозное, антиеврейское Авижение. В Польше евреи, с налогово-бюджетной точки зрения, мало отличались от остальных налоговых сословий и выплачивали в пользу короны регулярные налоги. ОАним из них был подушный налог который был имущественным налогом и устанавливался в общей сумме составлявшей во второй половине XV в. 900-1000 золотых, ответственность за этот общинный налог возцагалась на еврейских руководителей или специальных сборщиков. Во время войн на евреев налагались чрезвычайные налоги, например в 1496 г. евреев обязали уплатить по одному злотому за кажАого мужчину и по Авенадцать грошей за женщин и Аетей, прислугу.

\section{ПРАВОВЫЕ ОТНОШЕНИЯ ХРИСТИАН И ЕВРЕЕВ В МУСУАЬМАНСКОЙ СРЕАНЕЙ АЗИИ}

Изгнание евреев с Европы стало причиной наплыва евреев в мусульманские земли. Изначально Средняя Азия была уже частично населена христианами и евреями. Так на археологических раскопках на Иссык-Куле, предположительно в бухте Курменты, было найлено большое количество остатков христианских церквей и монастырей несторианского толка (VII VIII вв.). На основе этого утвержАают, что в Средней Азии в средневековье преимущественно были христиане несторианского толка. (Горячева \& Перегудова, 1998, стр. 84-89). Несторианские находки, которые были найдены в конце XIX века на территории Кыргызстана ${ }^{17}$ можно найти в книге Четин Ажумагулова Кыргызстандагы несториан-түрк жазуу эстеликтери (XIII-XIV кылымдар) (Бишкек: Avrasya Press, 2014). Эта книга уникальна тем, что в нем есть много упоминаний о многочисленных надписях надгробных камнях кладбищя. (Жумагулов, 2014, стр. 5, 7) Учитывая, что некоторые из этих камней были написаны по-турецки, ${ }^{18}$ можно сказать, что христианство исповедовали не только ученики и последователи Несториана из Византии, но и тюркоязычные местные общины. (Жумагулов, 2014, стр. 456-463) Также о том, что Аоисламское христианство было широко распространено среди кочевых тюркских народов Средней Азии, свидетельствуют работы некоторых ученых. (Буряков, Жукова, \& Проскурин, 1998, стр. 9) Известно также, что монгольские племена обратились в несторианство в найманскую и керейскую эпохи. Известно, что некоторые из этих племен ассимилировались с тюркскими народами. Например, к кыргызам относятся племена найман и кереит. Ажон Плано Карпини пишет, что Батый (внук Чингисхана, сына Ажучи, правившего в свое время Золотой Ордой) держал с собой несторианских священнослужителей. Хорошо известно, что несториане пользовались в то время значительной подлержкой среди монголов. (БартольА, 1996, стр. 134).

По источникам Бируни несториане составляли большинство населения в Хорасане. БагдаАский географ и путешественник Хв. Абуль-Касим МухаммаА бин Хаукаль ан-Нисиби сообщает о наличии христианских селений ВазкерА на горе Шавдар к югу от Самарканда, и

\footnotetext{
15 Наряду с этими ежегодными налогами особый коронационный налог взыскивался с евреев на каждую коронацию; он составлял от $1 / 4$ до 1/3 стоимости имущества еврея. Так, в 1438 г. австрийское еврейство уплатило коронационный налог в сумме 156 тыс. золотых флоринов. Тяжелым бременем Аожились на евреев и военные поборы. За одно столетие военный налог вводился 15 раз (1396, 1422, 1425, 1427, 1430, 1432, 1462, 1463, 1470, 1475, 1484, 1486, 1491, 1494, 1499). Величина налога была различной. В 1422 г. от евреев потребовали выплатить превышавшую $10 \%$ стоимости их собственности сумму на покрытие расходов, связанных с войной с гуситами; в 1427 г. военный налог составиц один золотой флорин с человека вне зависимости от пола и возраста еврея; в 1475 г. евреи должны были поставить четыречта фунтов пороха Аля войны против Венгрии.

17 В 1880-х годах возле городов Пишпек и Токмак было открыто старинное христианское кладбище.

${ }_{18}$ На высеченных погреб̆альных плитках умерших есть турецкие имена как Айменгу, Алма-Катун, Алтун, Арслан, ЙокТегин, Йом-Кутлук.
} 
Винкерд в Уструшане, на границе с Чачем (Шаш). Ааже период монгольских нашествий в Средней Азии не стало им препятствием Аля их развития. (БартольА, 1996, стр. 269). В источниках Казвини сообщается о сохранении христианского населения в вышеперечисленных городах вплоть Ао ХІІв. (Петрушевский, 1966, стр. 145).

Нужно заметить, что оживление и процветание несторианской Аеятельности в Средней Азии в средневековья приходилось именно на время активного арабско-мусульмского завоевания. Также христиане-сирийцы (большинство представителей несторианства) занимали высокие административные Аолжности у мусульманских правителей. Их деятельность связана со временем католикоса Тимофея I (778 - 823). Сообщается о миссии монаха Шубхалишо из ассирийского монастыря Бет-Хобех в районы от Прикаспия до Центральной Азии и Китая. Ему приписывается обращение в христианство несторианского толка, помимо язычников и манихеев, огнепоклонников, а также христиан-маркионитов. (Никитин, 1984, стр. 126).

В результате исследований Перегудовой в 1978-1980 гг., Таш-Рабат в Центральном ТяньШане которое долгое время считался Рабатом, позволило передатировать появление зАания ТашРабат в Х в. и трактовать его как жилище «монастырского типа». (Горячева \& Перегудова, 1998, стр. 89). Из этого утверждения становиться ясным, что Таш-Рабат является несторианским монастырем, хотя побывавший в Таш Рабат будАийский монах из Японии Тарасава-Сан в интервью журнацу «Мээрим» утверждает, что это будАийский храм. Во многих арабских источниках средневековья указывается наличие целых христианских городов, и наличие преАставителей разных течений христианства на территории Средней Азии. Так Ан-Недим, в первой половине VIII в. приводит слова Аостойного свидетеля, по которым жители города Согдианы были Ауалистами и христианами. (БартольА, 1996, стр. 264). В начальный периол прихода ислама в Среднюю Азию часть церквей и монастырей христиан были преобразованы в мечети, так в 893/894 г. эмиром Исмаилом сообщает Макдиси главная церковь в Казахстане город Тараз превратилась в соборную мечеть. (Бартольд, 1996, стр. 269). По словам Нершахи, мечеть арабского племени Бенуханзаля в городе Бухара находилась на месте христианской церкви. Аналогичная ситуация повторилась и в городе Мерке мечеть располагалась в зАании бывшей церкви. В свое время Истахри упоминац о христианской церкви около Герата. В то же время Абу Аулаф упоминает, что у племени гузов, обитавших вблизи города Хорезм, был большой христианский храм, без изображений, а также о том, что среди племени Ажикиль ${ }^{19}$ было много христиан. (БартольА, 1996, стр. 277-278). Так Шериф аА-Аин, говоря о событиях накануне монгольского завоевания, говорит, что дочь каракиАанского гурхана из рода ЕАюй Ааши, которая в последствии становиться женой Кучлука, была представительницей христианства. (БартольА, 1996, стр. 285). Сам же Кучлук до монгольского нашествия так же был христианином. (БартольА, 1996, стр. 288). Также Аругие источники (Абу Аулафа и ал-Асира) указывают на наличие монофизитов в СреАней Азии. (Советский энциклопедический словарь, 1983, стр. 1846). ${ }^{20}$

В своих работах Бируни грамотно проводит разАичие межАу мелькитами, несторианами, яковитами и другими христианскими направлениями, которые обитали в СреАней Азии. Термин «мелькиты» происходит от элАинизированной формы сирийского прилагательного «малкайя»имперский: монофиситы называли «имперскими Аюдьми» тех христиан Сирии и Египта, которые отвергли монофиситство и несторианство, сохранив верность подлерживаемому византийским императором православию (Советский энциклопедический словарь, 1983, стр. 1812). Причем последние подчинялись митрополиту города Хорасан. Мелькиты Хорасана, могли праздновать день Иоана-младшего Мученика из Мерва. Это указывает на наличие в городах хорошо закрепившиеся религиозной - церковной организации мелькитов, которая смогла канонизовать своих мучеников - последователей. Бируни утвержАал, что большинство жителей Сирии, Ирака и Хорасана несториане: «Католикоса несториан назначает повелитель правоверных с согласия общины несторианы». Также он Аостаточно подробно пишет о мелькитах, указывая конкретные города, на наличие их церковного календаря. Закария Казвини и аль-Асир утвержАали, что там где власть осталась в руках христиан, при этом земля была мусульманской, мусульманские купцы облогались податью. (Петрушевский, 1966, стр. 143-144). Эта благоприятная среда мля

\footnotetext{
19 основное население города Хорезм.

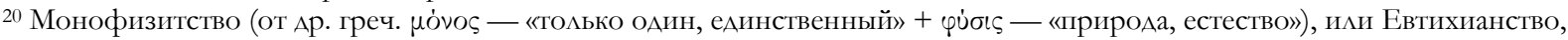
Христологическая Аоктрина в христианстве, постулирующая наличие только одной, единственной Божественной природы (естества) в Иисусе Христе и отвергающая Его подлинное человечество.
} 
христиан в Средней Азии было причиной развития и Аля иудаизма на территории Средней Азии, которые в последствии сыграли значительную роль на экономику Средней Азии среАневековья. Еврейские торговцы Раданиты играли большую роль в развитии Шелкового Пути. Развивались Бухара, Самарканд, Тирмиз, Мерв и Ургенч давно стали большими и процветающими городами благодаря тому, что эта Аорога позволяет вести активную и интенсивную коммерческую Аеятельность. (Аресвянская, 2004, стр. 21). Надо отметить, что на землях захваченными арабамимусульманами в общей сложности проживало около 90 процентов евреев мира, при этом арабы сохранили независимость еврейских общин, которым было разрешено свободно жить по законам Торы. В Средней Азии по словам Макдиси в государстве Саманидов еврейское население преобладало христиан. (БартольА, 1996, стр. 269). Все это указывает на наличие евреев до арабских завоеваний. Так в Центральной Азии в целом возникали важные еврейские поселения, в том числе Бактрия-Тохаристан, СогА, Маргиана и Хорезм. (Ртвеладзе, 2004, стр. 12). Согласно по информации переданным Гретсем, евреи распространились в городе Бухара до города Хива, и в этом регионе проживали восемь тысяч еврейских семей. По записям Бенджамин Туделы в Самарканде проживало пять десять тысяч евреев. (Benjamin-Ratisbonlu Petachia, 2001, s. 77). B VIII веке, когда мусульмане захватили регион, евреи уже населяли Бухару. Во время завоевания Тимуром региона, упоминались евреи живущие в Бухаре и Самарканде. (Гуревич, 1995, стр. 71). Ташкентские евреи признают, что их предки четыреста мет назаА прибыли из Бухары, и что большинство из них занимались и занимаются производством и продажей шелковых тканей...». Позднее евреи живущие в Бухаре и Самарканде, были замечены в других городах Ферганской Аолины (Голендер, 2004, стр. 66-67).

Представители христианской религии влияли на развитие уровня жизни крупных городов Средней Азии, так в городе Мерв с IV в. существовала самостоятельная епархия, которая в 420 г. преобразовалась в митрополию. В V-VII вв. Этот город был одним из главных духовных центров Средней Азии. После того как евреи были изгнаны из Европы, и переселены в Центральную Азию их ремеслом стало торговля в том числе и межАународная (по Шелковому Пути) они использовали знание арамейского языка и письменность, занимались торговлей по всей Азии достигая Синьцзян. Еврейские купцы раданиты вели свои караваны на восток в Китай и на запад в Европу. Они установили много торговых постов по дороге в Китай, где многие из них остались поселившись там. Проф. М. ЗанА утвержАал, что евреи уже с IV в. были расселены в городах вдоль Великого Шелкового Пути. (Хар-ЭАь (Бабаев), 1992, стр. 319-320). Известный путешественник Марко Поло, проходивший в XIII веке через территорию современного Кыргызстана в Китай, писал в «Путешествиях» о непростых отношениях китайских евреев с христианами - несторианами. Так же он пишет, что в Китае в разных районах существовали еврейские общины, которым с XII века было разрешено иметь свои молельные храмы - синагоги. Но несмотря на это евреи начали ассимилироваться и смешались с китайской культурой. (ФицАжеральА, 1998, стр. 247). Причиной этому послужило то, что евреи Средней Азии находясь в Аали от центральной синагоги Вавилона начали развивать новые измененные взгяяды на иудаизм как таковой, начинаются пренебрежения Торой.

Бартольд указывал что в X веке в восточном Шаше евреи превосходили христиан, также еврейский путешественник Биньямин ТуделАа (XII век) впервые в письменном виде упоминает о существовании евреев в Средней Азии (Фазылов \& Березнякова, 1992, стр. 26, 128), в них говорится что в Самарканде проживает не менее 30.000 евреев. Такое количество евреев в центральных городах Средней Азии указывает на что евреи жили и в других крупных городах как Бухара, Мерва, Термез, Балх, Герат, Нишапури и Ургенч. (Рюкуа, 2014, стр. 358).21 В XII веке Бенджамин из Тудемла писал, что в ранний исламский период, крупнейшим центром еврейской общины в Средней Азии был Самарканд. Евреи в этих городах были довольно известны, были среди них ученые, врачи, переводчики, торговцы, ремесленники, ювелиры, менялы, чеканщиками монет, красильщики шелка, цирюльники, сапожники, мясники и кузнецы. Среди них Абуль-Хасан Али бин Сахль Раббан ат-Табари (870) — врач, создатель первой энциклопедии по медицине, психолог, пионер педиатрии. Учитель знаменитого персидского врача Абу Бакр ар-Рази, также он

\footnotetext{
${ }^{21}$ Бенджамин из Туделы (ок. 1130-1175). Еврейский торговец, родившийся в наваррском городе Тудела, Бенджамин бен Йонах получил хорошее образование и знал несколько языков. После своих многочисленных путешествий и Аипломатических поездок от Средиземноморья до Парижа он написал «Книгу путешествий» (Sefer Masa'ot) в которой содержались сведения по экономике, политике и демографии, а также по навигации, по расстояниям и хронологии, что стало ценным источником знаний XII века. Он возвратился в Туделу в 1173 году.
} 
был известен как первый шахматист - еврей, он был родом из Табаристана (Каспийское море) который славился среди арабов, как врач и математик. Он перевёл на арабский язык Альмагест греческого астронома Птолемея. Позже по приказу Тимура в XIV в. после взятия Бухары были переселены несколько сот еврейских семей в Самарканд, эта новая еврейская община уже современной истории называется «Бухарской».

На экономическом рынке Средней Азии евреи всегАа развивались быстро, развивали денежный бизнес среди них были известные чеканщики монет. Аля евреев синагоги не могли быть местом хранения вкцадов еврейской общины страны, изгнание евреев и плачевное положение евреев в Европе Аали подлержку мусульман, в следствии этого еврейские европейские вкладчики и Аепозиторы считали исламские страны надежными хранителями денежных средств, которые в то же время могли принести значительные выгоды и евреям, и государству хранителю. Аругой араб́ский автор, МукаАдаси (Хв.), отмечает, что «бооььшая часть сортировщиков зерна, красильщиков и Аубильщиков это евреи, тогАа как врачи и писцы обычно христиане», а также на административных АОАжностях, образуют нечто вроде еврейской социальной службы. Эти профессии в Средней Азии, как и в Европе были очень важными. Показателем этого явАяется переселение всех византийских евреев в города Фива в Южную Италию который осуществил неаполитанский король Роже II в 1147 гоАу, это были евреи которые производили щелк, и красили ткани. Также есть предположение что Бухарские евреи Средней Азии были связаны межАу собой с этими итальянскими евреями.

Разнообразие профессий евреев на территории Средней Азии объяснялось открытым характером мусульманского общества и в отличии от Европы, высокой степенью экономического равенства Аля представителей всех вероисповеАаний. Ааже там, гАе существовало нечто вроде гильдий, мусульмане не претендовали на монополию и не проводили политики Аискриминации по отношению к евреям-ремесленникам, как это было в христианской Европе.

Торговля как в Европе, так и в Средней Азии считалась для евреев выгодным и более престижным занятием, чем сельское хозяйство, да и потому что налоги не оправдывали их доход. Евреи стали конкурировать с греками, армянами, сирийцами и самими арабами в торговле межАу крупными городами халифата. По причине схожести арабского и иврита у евреев было преимущество в межАународной торговле. В своей рукописи «Киттаб аА-масаАик» («Книга путей», 846 г., 2-е изА., 886 г.) Ибн ХурАаАбих описывает странствия раданитов из Северной Франции и Южного Марокко в Индию и Китай: «Эти купщы говорят по-арабскки, по-персидски, по-ромейски (греческий и матинский языки), на языках франков, испанцев и славян. Они путешествуют с ЗапаАа на Восток и с Востока на ЗапаА, и по суше и морем. Они везут с Запада евнухов, рабынь, мальчиков, бархат, бобров, мечей, куниц и прочие меха. Они ведут корабли из Фиранджи (Франции) на Западном море и илут в Фараму (Пелузий, ныне Балуза на средиземноморском побережье Синайского полуострова). На обратном пути из Китая они везут мускус, алоэ, камфару, гвоздику и Аругие продукты восточных стран... Некоторые иАут в Константинополь, чтобы продать свои товары ромеям, Аругие иАут во Аворец короля франков... Эти пути могут быть также пройдены и по суше». Некоторые евреи-полиглоты служили переводчиками при Аворе в Европе. Известно, что некий еврей по имени Самлам достиг в 845 г. «стены Гога и Магога» в Китае, он говорил на 50 языках. Аокументы на разных языках найдены также в Каирской генизе. КогАа КарА Великий король франков (768-814) и первый император Римской империи (с 800 г.), внук Карла Мартелла решил послать посольство к Абу Ажафар Харун бин МухаммаА, более известный как Харун ар-Рашиду арабскому халифу, правителю Аббаситского халифата (786 (с 14 сентября) 809 г.,) ему пришлось ввести в состав посольства еврея-переводчика Исаака. В дороге благородные послы скончались, и Исаак вернулся из Багдада один, везя дары Харун ар Рашида императору Карла Мартемле.

\section{Выводы:}

Целью Аанной статьи является разрушение ошибочного представления о плачевном состоянии немусульман в исламской мире и описания ислама как об агресивной и нетирпимой религией к Аругим религиям. Используя специально-исторические методы (историкосравнительные, сравнительно-сопоставительные методы) мы проверили гипотезу агрессивности религии ислам, и пришли к выводу что многие европейские источники имели специфическую миссионерскую, противоисламскую направленность. Были использованы книги по истории 
ислама затрагивающие вопросы исламо-христианского, еврейско-христианского межрелигиозного, межкультурного взаимодействия в Средние Века в целом. Кроме того, эти результаты дают Аополнительную информацию о положении немусульман в Аругих господствующих религиях средневековья. Выявляются разАичия причин и целей возвышения и появления новых налогов как в мусульманских странах, так и Европы. Также широкое значение Аанного исследования состоит в том, что Аля большей объективности в статье были использованы разносторонние материалы. Также мы постарались разъяснять суть исламского налогообложения зиммиев чтобы понять юридическую обязательность и разницу между мусульманским и немусульманским налогом в обществе. Юридическая обязательность уплаты закята была подкреплена моральной сторонойзакят яв яется одной из обязанностей кажАого Аееспособного мусульманина, он взимается с имущества безвозмездно, принаАлежащего конкретному человеку, при этом плательщик закята ничего не получает взамен. Каноны религии учит справедливости, Аоброму отношению и терпимости к окружающим в том числе и к немусульманам в их государстве. Шариат не скрывает что целью обложения налогами как иноверцев и кяфиров является привлечения иноверцев к исламу. Таким образом оАним из функций налоговой системы ислама, можно назвать «Ааватом» призывом, миссионерством. Именно этот аспект мусульманского законодательства о налогах служиц оАной из главных причин массового перехода в ислам христиан, иудеев и язычников в раннем средневековье, и в отличии от Европы каноны ислама не заставляло «Аюдей Писания» принудительно принимать религию. Аля них шариатом были созданы благоприятные условия, в которых они могли свободно придерживаться своей религии, Аля этого они из статуса «АюАей Писания» переходили в статус «покровительствуемых» - зимми. В каноническом шариате под термином зимми подразумевались иудеи, христиане, самаритяне, при этом шариат в понятие зимми не вкладывает никакого признака национальной принадлежности. Слова Умар бин Хаттаба основателя исламской экономики о том, что Имам (правитель мусульманского государства) подобен остальным АюАям и не имеет никакого обоснованного исламом права получать что-либо прежде остальных или брать больше других служит подтверждением этому. Именно благодаря исламскому вероучению мусульмане были терпимы к иудеям и христианам. «В челом отношение мусульман к "покровительствуемьим" (иудемм и христианам) было терпимьм, если не вмешивались внешнеполитическе и военные факторы. Наиболее благоприятныл было положение иудеев, за которыми не стояла никакая внешняя сила. Ааже во время войн с крестоносиами мусульмане были настроены к христианам менее враждебно, чем крестоносиь к мусульманам... Положение христиан и иудеев в странах ислама было значительно более благоприятньм, чем положение иноверчев в странах средневековой Европь. Часто иудеи и даже восточные христиане предпочитали жить под властью мусуьманских, а не европейских христианких правителей». (Негря, Ислам: энциклопедический словарь, 1991, стр. 28-29). Если в Европе абсолютно все иноверцы приравнивались к неверным, и принуждались к переходу в их религию поА страхом смерти, то ислам создавал все условия Аля возможности сохранить свою религию и имущество. Журавский писал о том, что «проблема сосуществования ислама с конфессиональными меньшинствами, соответствует исламскому вероучению. "Классический ислам признает 3 статуса существования человека: в качестве а) "правоверного”, б) “покровительствуемого”, в) “многобожника". "Покровительствуемьге” это "Аюди Писания", т. е. иудеи и христиане, которым, как и мусльманам, было ниспослано Божественное откровение, и которые веруют в Единого Бога, пророчества и судный день... За ними признавалось право на существование в качестве инорелигиозных общин при условии выплаты ими наряду с обязательной для всех подданньгх поземельной податью харадж спещиального подушного налога джизвя». (Журавлевский, 1990, стр. 83). Так по Канонам Ислама христиане и иудеи относятся к категории мюдей Священного Писания и что иноверец (христианин и иудей) и неверный по шариату не синонимы, и в связи с этим, религия ислам признает истинность библейских пророков от Авраама - Ибрахима, Моисея -

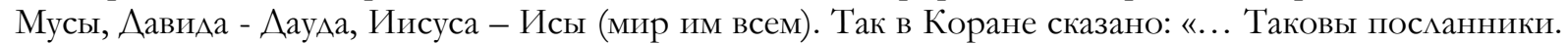
ОАним из них, Мы отАали предпочтение перед Аругими. Среди них были такие с кем говорил А^ıах, а некоторых из них А^лах возвысиц до степеней. Мы даровали Исе (Иисусу), сыну Марьям (Марии)» 2-253. (Аль Корануль Карим (перевод на русском языке с комментаниями), 2010, стр. 134), «Или же вьг находились рядом, когда смерть явилась к Якубу (Иакову)? Он сказал своим сьгновьям: «Кому ввь будете поклонаться после меня?». Они сказали: «Мвг будем поклонаться твоему Богу и Богу твоих отуов Ибрахима (Авраама), Исмаила (Измаила), Исхака (Исаака), Единственному Богу. Ему одному мьг покоряемся». (А^ь Корануль Карим (перевод на русском языке с комментаниями), 2010, стр. 74-75). В Канонах Ислама оговаривается каждая деталь в плоть до разрешения споров Аля соблюдения справедливости и сохранения мира между мусульманами и не мусульманами. Так, в Коране говорится: «Если вступаете в спор с людьми Писания, то ведите его наилучиим образом. Это не относится $\mathcal{\kappa}$ 
тем из них, которые поступатот несправедливо. Скажите: «Мвь уверовали в то, что ниспослано нам, и то, ито ниспослано вам. Наш Бог и ваш Бог - один, и мьг покоряемся только Ему». 45:28. (Смысловой перевод Священного Корана на русский язык, 1437х., 2015, стр. 650). «B тот Аенъ, когда настанет Cудный час, тыг увидишь, о тот, к которому обращена речь, последователей каждой религии коленопреклонённыли от ужасов этого Аня, готовыли идти на зов; каждая община будет призвана к Книге записей своих деяний и будет им сказано: Сегодня вам воздастся за ваши деяния, которые вы совериили в земном мире». (Смысловой перевод Священного Корана на русский язык, 1437х., 2015, стр. 650). (43 الإمام أبي عبيد القاسم، صفحة). Понимая суть этих аятов и придерживаясь их, правители исламского государства максимально старались подлерживать все слои немусульманского населения их земель. А^я беспомощных неимущих (вне зависимости от религии и нации), кто не мог обеспечить себя по каким-либо причинам вылелялись различные постоянные пособии. Так пятый праведный халиф Умар бин Аблулазиз написал своему поданному в Басре (Ирак) 'ААийу бин Арта: «Посмотри на старых и слабых немусульман, живущих на территории мусульман на договорных основах-зимми, которые Аишены своего заработка и вылели им пособия из имущества мусульман, чтобы улучшить их состояние». КогАа один из подчиненных Умара принес ему сумму Ажизьи, взятую с немусульман, ему показалось что этого много, и он сказал тому, «Я Аумаю, вы погубили Аюдей». Подчиненный сказал: «ет, клянусь Алмахом, мы взяли только излишки и то, что Аавали искренно». Умар спросил: «Без кнута и без подвешивания»? Тот сказал: «Аа». Умар сказал: «Хвала А^^аху, который не допустил это под моей властью и во время моей власти». (الإمام أبي عبيد القاسم، صفحة 43). Так переА смертью Умар бин Хаттаб основатель исламской экономики завещал всем мусульманам позаботиться о тех, кто находиться поА их покровительством (зимми) говоря: «Я завещаю халифам, после меня, чтобы они относились хорошо к Аюдям, находящимся поА защитой мусульман и живущим на их территории, чтобы они защищали их и не возАагали на них то, что им не под силу». Таким образом все последующие халифы заключали договора с зиммиями об их свободном исповедовании своей религии, о выплате джизьи и официально браАи их под защиту исламского государства. «С именем Алмаха, Милостивого, Милосердного! 'Амр бин аль-'Ас гарантирует жителям Египта неприкосновенность их жизней, имущества и религии, их храмов и крестов, их суши и моря. Никто не имеет права входить к ним против их воли или забирать у них что-либо... Этот Аоговор Аарован вам А^^ахом и Его Посланником, и халифы и все верующие обязуются соблюдать его». Умар разъяснил правила, регулирующие взаимоотношения мусульман с зиммиями: «Мы обещали им оставить им их храмы, в которых они могут говорить, что поже ают, и не возлагать на них ничего непосильного. А если враг захочет причинить им зло, мы обязуемся защищать их. Мы также предоставляем им возможность решать дела в соответствии с нормами их религии, если только сами они не обратятся к нам на суд, соглашаясь с законами нашей религии, и тогда мы вынесем решение Аля них. Если же они не пожелают обращаться к нам, мы не станем трогать их». (Ат-Табари, 1987, стр. 218). Религия ислам также не принуждал и непринуждает принимать религию насильно, позволиц им иметь свои храмы и не разрушал кроме илолов, и за искцючением того, что храмы пустовали по причине большого количества перехода зимми в ислам. (Умар ибн аль-Хаттаб. Второй праведный халиф, 2011, стр. 137). Более того, такое же явление, Аобровольной передачи пустующих храмов практикуется и в наши Ани в Европе. Так по данным американского Gatestone Institute в Аондоне начиная с начала 2000 годов закрылось примерно 500 церквей разных конфессий, часть из которых превращены в музеи, спорт залы и какая-то часть в места моления мечети Аля мусульман. Опять же по прогнозу организации Christian Research, к 2020 году в Англии закрылись еще 4000 храмов. По информации британской Guardian причиной этому послужило сокращение посетителей церквей Ао 760000 в воскресные службы. Также по информации Spiegel, только у Евангелической церкви Германии с 1990 по 2010 гол было закрыто 340 церквей (46 из них было разрушено), они превращены в зАания разного назначения. Такое же превращение мечетей в церкви наблюдалось европейских мусульманских странах. На Аанный момент в Болгарии 117 мечетей, более шести мавзолеев и медресе, в Хорватии три мечети и часовня, в Крыму шесть мечетей и мавзолеев, в Венгрии 23 мечети, 5 мавзолеев, баня и одна школа Османской империи были принудительно превращены в церкви (Ekip \& Asgarli , 2020). Эти показатели являются доказательством того, что переформирование мусульманами церквей и синагог в средневековье практиковалось, как и в те времена у Аругих народов так же и в наши дни.

В целом в статье приведены примеры налогов, которыми облогались иудеи и христиане в мусульманском обществе. Еще одно направление исследования - это проблема общего и 
особенного в понятии налогообложения ислама и христианства. Работа нацелена, во-первых, на истолкование разАичия и сходства до исламских религий и господствующих религий процветающего в эту эпоху европейских стран; во-вторых, на уяснении специфики отношения христианской и исламской культур к «неверным», «иноверующим». Надеюсь, что Аанные исследования могут быть использованы при разработке и преподавании общих и специализированных курсов по истории и культуре арабо-исламской и запаАно-европейской цивилизаций в Средние Века, на курсах по истории и теории исламо-христианского, исламоеврейского межкультурного Аиалога, а также послужит материалом Аля улучшения межрелигиозных отношений на территории СреАней Азии.

\section{Список Аитературы}

Benjamin-Ratisbonlu Petachia, T. (2001). Orta Cağda İki Yabudi Seyyabin Avrupa, Asya ve Afrika Gözlemleri, (Çev. Nuh Arslantas). (A. Arslantaş, Çev.) İstanbul: Kaknüs Yayınları.

Ekip, K. ve Asgarlı , А. (16 июль 2020 г.). Объекты исламского наследия передалотся под нужды черквей, в особенности в Венгрии, Болгарии и Гречии. Получено из аa.com.tr: www.aa.com.tr/ru. / Ekip, K. ve Asgarli, А. (16 июль 2020 g.). Obyekti islamskogo naslediya peredayutsa pod nuzhdy tserkvey, v osobennosti v Vengrii, Bolgarii i Gretsii. Polucheno iz aa.com.tr: www.aa.com.tr/ru

Sevilla - Şaron, M. (1992). Türkiye Yabudileri. İstanbul: İletişim Yayınları.

Абу Хасан, М. Н. (2002). Начало распространения ислама на территории Кыргызстана (середина $\backslash$-Х вв.). Вестник Кьгргъзско-Российского Славянском ушверситета(№4). / Abu Khasan, M. N. (2002). Nachalo rasprostranenya islama na territorii Kyrgyzstana (seredyina VIII - X vv.). Vestnik Kyrgyzsko-Rossiyskogo Slavyanskogo universiteta (№4).

Адамс, Ч. (2018). Влияние налогов на становление чивилизачий. (А. А. Столяров, \& А. А. Резвов, Перев.) Москва. / Adams, Ch. (2018). Vliyanie nalogov na stanovlenie tsivilizatsiy. (A. A. Stolyarov, \& A. A. Rezvov, Perev.) Moskva.

Алексеев, Ю. Г., Клеандрова, В. М., Новицкая, Т. Е., Семилеркин, Н. А., Щапов, Я. М., Честяков, О. И., \& Янин, В. А. (1984). Законодательство Аревней Руси. Российское законодательство Х-ХХ веков. (Т. 1). Москва: Юридическая митература Москва. / Alekseev, Yu. G., Kleandrova, V. M., Novitskaya, T. Ye., Semiderkin, N. A., Shapov, Ya. M., Chestyakov, O. I., Yanin, V. L. (1984). Zakonodatelstvo Drevney Rusi. Rossiyskoe zakonodatelstvo X-XX vekov. (T. 1). Moskva: Yuridicheskaya literatura. Moskva.

Аль Корануль Карим (перевод на русском языке с комментаниями) (изА. 1, Т. 1). (2010). (А. Орияхили, \& Ф. Шафик, Перев.) Стамбул: Издательский Аом Мильсан. / Al Koranul Karim (perevod na russkom yazyke s kommentariyami) (izd. 1, T. 1). (2010). (A. Oriyakhili, F. Shafik, Perev.) Stambul: Izdatelskiy Dom Milsan.

Амрахов, М. И. (2011). Возникновение государственности и формы землевладения у тюрков. Учебное пособие. Баку: Мутарджим. / Amrakhov, M. I. (2011). Vozniknovenie gosudarstvennosti i formy zemlevladeniya u tyurkov. Uchebnoe posobie. Baku: Mutardzhim

Ат-Табари, М. (1987). История ат-Табари. (О. Г. Большаков, А. Б. Халидов, \& В. И. Беляев, Перев.) Ташкент: Фан. / At-Tabari, M. (1987). Istoriya at-Tabari. (O. G. Bolshakov, A. B. Khalidov, V. I. Belyaev, Perev.) Tashkent: Fan.

Бабавей, Н. А. (2002). Распространение Ислама под остриём меча - между истиной и измыилением. Каир: Заведение Бабавей Аля печати. / Babavey, N. L. (2002). Rasprostranenie Islama pod ostriyom mecha - mezhdu istinoy i izmyshleniem. Kair: Zavedenie Babavey dlya pechati.

Бартольд, В. В. (1996). Избранные трудъ по истории Кьргызстана. О христианстве в Туркестане в домонгольский период. Бишкек: Шам. / Bartold, V. V. (1996). Izbrannye trudy po istorii Kyrgyzstana. O khristianstve v Turkestane v domongolskiy period. Bishkek: Sham.

Беккин, Р. И. (2008). Исламская экономика. Москва: Восток-ЗапаА. / Bekkin, R. I. (2008). Islamskaya ekonomika. Moskva: Vostok-Zapad.

Белковец, А. П., \& Белковец, В. В. (2000). История государства и права России. Курс лекиий. Новосибирск: Новосибирское книжное издательство. / Belkovets, L. P., Belkovets, V. V. (2000). Istoriya gosudarstva i prava Rossii. Kurs lektsiy. Novosibirsk: Novosibirskoe knizhnoe izdatelstvo

Библия. Книги священного писания (Ветхого и Нового Завета канонические). (1994). Можайск, Россия: Можайский полиграфический комбинат Министерства печати и информации Российской Федерации. / Bibliya. Knigi svyaschennogo pisaniya (Vetkhogo i Novogo Zaveta kanonicheskie). (1994). Mozhaysk, Rossiya: Mozhayskiy poligraficheskiy kombinat Ministerstva pechati i informatsii Rossiyskoy Federatsii.

Быля, А. Б. (2013). История налогообложения и взгляды на налоги А. Смита и А. Рикардо. ФИНАНСОВОЕ ПРАВО И УПРАВАЕНИЕ, 141. / Bylya, А. В. (2013). Istoriya nalogooblojeniya i vzglyady na nalogi A. Smita i D. Rikardo. FINANSOVOE PRAVO I UPRAVLENIE.

Введение в Ислам. (Мухтасар илъми-халь). (2009). Бишкек. / Vvedenie v Islam. (Mukhtasar il'mi-khal). (2009). Bishkek.

Вихнович, В. А. (2006). Религии мира - Иудаизм. Санкт Петербург: Издательский дом Питер. / Vikhnovich, V. L. (2006). Religii mira - Iudaizm. Sankt Peterburg: Izdatelskiy dom Piter. 
Голенлер, Б. А. (2004). Туркестан на стариннъх почтовых открытках. Ташкент: Фан. / Golender, В. А. (2004). Turkestan na starinnyx pochtovykh otkrytkakh. Tashkent: Fan.

Горячева, И. А., \& Перегудова, С. Я. (1998). Памятники христианства на территории Кыргызстана. В Из истории древних культов Средней Азии. Христианство. Ташкент. / Goryacheva, I. D., Peregudova, S. Ya. (1998). Pamyatniki khristianstva na territorii Kyrgyzstana. V iz istorii drevnikh kultov Sredney Azii. Khristianstvo. Tashkent.

Гуревич, А. А. (1995). Бъгтовое и сакральное пространство Махаллаи. Санкт Петербург. / Gurevich, L. D. (1995). Bytovoe i sakralnoe prostranstvo Makhallai. Sankt Peterburg.

Аресвянская, Г. Я. (2004). К истории иудаизма в Средней Азии. Евреи Средней Азии. Ташкент: Фан. / Dresvyanskaya, G. Ya. (2004). K istorii iudaizma v Sredney Azii. Yevrei Sredney Azii. Tashkent: Fan.

Журавлевский, А. В. (1990). Христианство и Ислам. Сочиокультурные проблемы диалога. Москва: Наука. / Zhuravlevskiy, A. V. (1990). Khristianstvo i Islam. Sotsiokulturnye problemy dialoga. Moskva: Nauka.

Игнатенко, А. А. (1980). Ибн Хальдун. Москва: Издательский Аом Мысль. / Ignatenko, А. А. (1980). Ibn Khaldun. Moskva: Izdatelskiy Dom Mysl.

Катюк, Г. П. (2016). Запад и Русъ. Истоки Противостояния. Москва: ААгоритм. / Katyuk, G. Р. (2016). Zapad i Rus. Istoki Protivostoyaniya. Moskva: Algoritm.

Керимов, Г. М. (1999). Шариат. Закон жизни мусульман. Москва: Аеном. / Kerimov, G. М. (1999). Shariat. Zakon zhizni musulman. Moskva: Lenom.

Клюня, В. А., Черновалов, А. В., Черновалова, Ж. В., \& Шмарловская, Г. А. (2006). История экономический учений. Учебное пособие для вузов. Минск: Новое знание. / Klyunya, V. L., Chernovalov, A. V., Chernovalova, J. V., Shmarlovskaya, G. A. (2006). Istoriya ekonomicheskih ucheniy. Uchebnoe posobie dlya vuzov. Minsk: Novoe znanie.

Крамер, С. Н. (1986). История восточной культуры (Т. 1). Москва. / Kramer, S. N. (1986). Istoriya vostochnoy kultury (T. 1). Moskva.

Крамер, С. Н. (2009). Шумеры. Москва: Издание Центрполиграф. / Kramer, S. N. (2009). Shumery. Moskva: Izdanie Tsentrpoligraf.

Крачковский, И. Ю. (б.А.). Избранные сочинения (Т. 1). (В. И. Беляев, \& Г. В. Церетели, РеА.). / Krachkovskiy, I. Yu. (b.d.). Izbrannye sochineniya (T. 1). (V. I. Belyaev, G. V. Sereteli, Red.

Крашенинникова, Н. А., \& Жилков, О. А. (РеА.). (1996). История государства и права зарубежных стран (Т. 1). Москва. / Krasheninnikova, N. A., Zhidkov, O. A. (Red.). (1996). Istoriya gosudarstva i prava zarubezhnyh stran (T. 1). Moskva.

Аившиц, В. А. (1999). Подати и повинности на Аревнем Востоке. Глава податей в Парфяском и Сасанидском Иране. Санкт Петербург. / Livshits, V. A. (1999). Podati i povinnosti na Drevnem Vostoke. Glava podatey v Parfyaskom i Sasanidskom Irane. Sankt Peterburg.

Аимор, О. (2013). Евреи и христиане: полемика и взаимовлияние культур. Открытый Университет Израиля. / Limor, O. (2013). Yevrei i khristiane: polemika i vzaimovliyanie kultur. Otkrytyy Universitet Izrailya.

Мамедзаде, А. А. (2013). Свобода совести. Истоки, становление, правовая охрана. Санкт Петербург: Юридический центр-Пресс. / Mamedzade, А. А. (2013). Svoboda sovesti. Istoki, stanovlenie, pravovaya okhrana. Sankt Peterburg: Yuridicheskiy sentr-Press.

Мец, А. (2013). Мусульманский ренессанс. В А. Мамедзаде, Свобода совести. Истоки, становление, правовая охрана. Монография. Санкт Петербург: Юридический центр-Пресс. / Mets, А. (2013). Musulmanskiy renessans. V A. Mamedzade, Svoboda sovesti. Istoki, stanovlenie, pravovaya ohrana. Monografiya. Sankt Peterburg: Yuridicheskiy sentr-Press.

Молдобаев, И. Б. (1999). Были ли къцгъззы христианами? Получено из КРСУ ИКР: http://www.history.krsu.edu.kg/ / Moldobaev, I. B. (1999). Byli li kyrgyzy xristianami? Polucheno iz KRSU IKR: http://www.history.krsu.edu.kg/.

Негря, А. В. (РеА.). (1991). Ислам: энииклопедический словаръ. Москва: Наука - ГАавная редакция восточной митературы. ИзА-во осуществлено совместно с предприятием «Аом Бируни». / Negrya, L. V. (Red.). (1991). Islam: entsiklopedicheskiy slovar. Moskva: Nauka - Glavnaya redaktsiya vostochnoy literatury. izd-vo osuschestvleno sovmestno s predpriyatiem «Dom Biruni».

Негря, А. В. (1998). Общественный строй Аравии. Москва: Наука. / Negrya, L. V. (1998). Obshestvenny stroy Aravii. Moskva: Nauka.

Никитин, Н. В. (1984). Христианство в Центральной Азии. Аревность и Средневековье. В Б. А. Аитвинский (РеА.). Наука. / Nikitin, N. V. (1984). Khristianstvo v Sentralnoy Azii. Drevnost i Srednevekovye. V B. A. Litvinskiy (Red.). Nauka.

Осипов, Ю. С. (РеА.). (2008). Большая российская энииклопедия (Т. 10). Москва. / Osipov, Yu. S. (Red.). (2008). Bolshaya rossiyskaya entsiklopediya (T. 10). Moskva.

Петрушевский, И. П. (1966). К истории христианства в Средней Азии. История и филология стран Ближнего Востока. [Православнылй] Палестинский сборник(15 (78)). / Petrushevskiy, I. P. (1966). K istorii khristianstva v Sredney Azii. Istoriya i filologiya stran Blizhnego Vostoka. [Pravoslavnyy] Palestinskiy sbornik(15 (78)). 
Прозоров, С. М. (Ред.). (1994). Хрестоматия по Исламу. (В. В. Полосин, Е. А. Резван, \& А. А. Кныш, Перев.) Москва: Наука. / Prozorov, S. M. (Red.). (1994). Khrestomatiya po Islamu. (V. V. Polosin, Ye. A. Rezvan, \& A. D. Knysh, Perev.) Moskva: Nauka.

Ртвеладзе, Э. В. (2004). Евреи иудаисты в доисламской Средней Азии. Ташкент: Фан. / Rtveladze, Е. V. (2004). Yevrei iudaisty v doislamskoy Sredney Azii. Tashkent: Fan.

Рюкуа, А. (2014). Средневековая Испания. - М., Вече, 2014. Москва: Вече. / Ryukua, А. (2014). Srednevekovaya Ispaniya. - M., Veche, 2014. Moskva: Veche.

Смит, А. (1962). Исследование о природе и причинах богатства народов. Москва. / Smit, А. (1962). Issledovanie о prirode i prichinakh bogatstva narodov. Moskva.

Смысловой перевод Священного Корана на русский язык. (1437х., 2015). (Э. Р. Кулиев, Перев.) Мадина: Комплекс им. короля Фах^а. / Smislovoy perevod Svyaschennogo Korana na russkiy yazyk. (1437x., 2015). (E. R. Kuliev, Perev.) Madina: Kompleks im. korolya Fakhda.

Советский энииклопедический словарь (изд. 2). (1983). Москва: Наука. / Sovetskiy entsiklopedicheskiy slovar (izd. 2). (1983). Moskva: Nauka.

Торнау, Н. Е. (1882). О праве собственности по мусльманскому законодательств. Санкт Петербург: Типография Императорской Академии наук. / Tornau, N. Ye. (1882). O prave sobstvennosti po musulmanskomu zakonodatelstvu. Sankt Peterburg: Tipografiya imperatorskoy Akademii nauk.

Умар ибн аль-Хаттаб. Второй праведный халиф. (2011). (К. Е. Сорокоумова, Перев.) Москва: Умма. doi: ISBN 978-5-94824-146-3. / Umar ibn al-Khattab. Vtoroy pravednyy khalif. (2011). (K. Ye. Sorokoumova, Perev.) Moskva: Umma. doi: ISBN 978-5-94824-146-3.

Урстанбеков, Б. У., \& Чороев, Т. К. (1990). Къгъъъз прозасы. Фрунзе: Кыргыз Совет Энциклопедиясынын башкы редакциясы. / Urstanbekov, B. U., \& Choroev, T. K. (1990). Kyrgyz prozasy. Frunze: Kyrgyz Sovet Entsiklopediyasynyn bashky redaktsiyasy.

Фазылов, М., \& Березнякова, С. (Ред.). (1992). Народы Средней Азии и Казахстана. Сборник статей и очерков о бухарских евреях Самарканда (1918-1993 г2.), 2. / Fazylov, M., \& Bereznyakova, S. (Red.). (1992). Narody Sredney Azii i Kazakhstana. Sbornik statey i ocherkov o bukharskikh yevreyakh Samarkanda (1918-1993 gg.), 2.

ФицджеральА, С. П. (1998). Китай. Краткая история культуръъ. Санкт Петербург. / Fitsdzherald, S. P. (1998). Kitay. Kratkaya istoriya kultury. Sankt Peterburg.

Хар-Эль (Бабаев), М. (1992). Евреи и Великий Шелковый путь - 1992. - № 12. - С.12; КЕЭ. - Т.4. - С.319-320. Ариэль, 4(№12), стр. 12. / Khar-El (Babaev), M. (1992). Yevrei i Velikiy Shelkovyy put - 1992. - № 12. - S.12; KEE. - T.4. - S.319-320. Ariel, 4(№12), str. 12.

Черкасова, И. В. (13 112012 г.). Налоги на землю согласно исламскому праву, содержание вилы. (С. В. Кивалов, РеА.) Актуальні проблеми держави і права(65, №2). / Cherkasova, I. V. (13 112012 g.). Nalogi na zemlyu soglasno islamskomu pravu, soderzhanie vidy. (S. V. Kivalov, Red.) Aktualnie problemi derzhavi i $\operatorname{prava}(65$, №2).

Якубовский, А. Ю. (1947). Об испольных арендах в Ираке в VIIІв. В Советское востоковедение. ИзАательство Академии Наук СССР. / Yakubovskiy, A. Yu. (1947). Ob ispolnykh arendakh v Irake v VIII v. V Sovetskoe vostokovedenie. izdatelstvo Akademii Nauk SSSR.

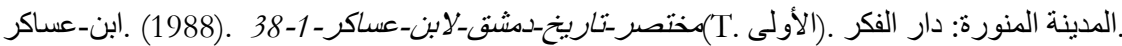

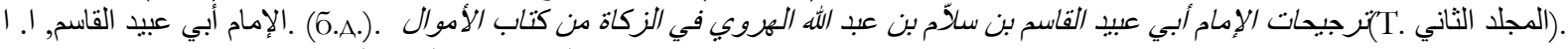

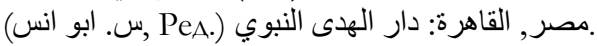

Mukhtasar, (al-Ulya), Tarih, Damashk, Li-İbni AsakirA, 38-1. (1988). Tarzhiylatu alimama Abi Abiyd Alkasim bin abdullah Alkharaviy fi Zakat minal amual. (b.d.) Misr, Alkahira, Darul Huda Nabauyy. (Red. S. Abu Anas) Madina al Munavvara.

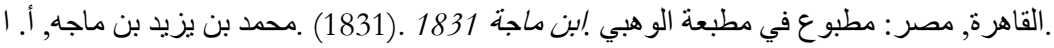

Ibnu Mazha. (1931). Muhammad bin Yaziyd bin Mazha. Misr. Alkahira. Matbu fi matba aluahabiy.

\section{EXTENDED ABSTRACT}

\section{Islamic taxation of Christians and Jews (zimmi) in Central Asia in the Middle Ages}

The purpose of this article is to destroy the misconception about the deplorable state of nonMuslims in the Islamic world, the destruction of the description of Islam as an aggressive and untrustworthy religion towards other religions. Using special historical methods, we tested the hypothesis of the aggressiveness of the religion of Islam, and concluded, that many European sources had a specific missionary, anti-Islamic orientation. We used books on the history of Islam touching upon the issues of Islamic-Christian, Jewish-Christian interreligious, intercultural interaction in the Middle Ages in general. In addition, these results provide additional information about the position of non-Muslims in other mainstream religions of the Middle Ages. The differences in the reasons and goals of the rise and appearance of new taxes both in Muslim countries and in Europe are revealed. 
Also, the broad significance of this study lies in the fact that for greater objectivity, various materials were used in the article. We also tried to clarify the essence of Islamic taxation of zimmies in order to understand the legal obligation and the difference between Muslim and non-Muslim tax. The legal obligation to pay zakat was supported by the moral side: zakat is one of the duties of every capable Muslim, it is levied on property belonging to a specific person free of charge, while the payer of zakat does not receive anything in return. The canons of religion teach justice, good attitude and tolerance towards others, including non-Muslims in their state. Sharia does not hide that the purpose of taxation as infidels and kafirs is to attract infidels to Islam. Thus, one of the functions of the tax system of Islam can be called "dawat"- missionary work. It was this aspect of Muslim tax legislation that served as one of the main reasons for the mass conversion of Christians, Jews and pagans to Islam in the early Middle Ages, and unlike Europe, the Canons of Islam did not force the "People of the Scriptures" to accept religion. Sharia created favorable conditions for them in which they could freely adhere to their religion. In Sharia, the term zimmi meant Jews, Christians, Samaritans, while the sharia does not put any sign of nationality into the concept of zimmi. It was thanks to the Islamic faith that Muslims were tolerant of Jews and Christians in their lands. "In general, the attitude of Muslims towards the "protected" was tolerant, if foreign policy and military factors did not interfere. The most favorable was the position of the Jews, behind whom there was no external force. Even during the wars with the crusaders, Muslims were less hostile to Christians than crusaders to Muslims. The position of Christians and Jews in the countries of Islam was much more favorable than the position of the Gentiles in the countries of medieval Europe. Jews and even Eastern Christians preferred to live under Muslim rather than European Christian rulers". If in Europe absolutely all gentiles were equated with infidels, and were forced to convert to their religion on pain of death, then Islam created all the conditions for the opportunity to preserve their religion and property. Juravlesky said the problem of the coexistence of Islam with confessional minorities corresponds to the Islamic faith. Classical Islam recognizes 3 statuses of human existence: as a) faithful, b) patronized, c) polytheist. The "Protected" are the "People of the Scriptures", that is, Jews and Christians, to whom, like Muslims, Divine revelation was sent down, and who believe in One God, prophecy and the day of judgment. They recognized the right to exist as non-religious communities on condition that they pay, along with the obligatory land tax haraj, a special poll tax, jizya, along with the obligatory for all subjects. The canons of Islam allowed them to have their own temples and did not destroy them except for idols and due to the fact that the temples were empty due to the large number of zimmis converting to Islam. By the way, the same phenomenon, the voluntary transfer of empty churches is practiced today in Europe. So, according to the American Gatestone Institute in London, since the beginning of 2000, about 500 churches of different confessions have been closed, some of which have been turned into museums, sports halls and some of them into places of prayer mosques for Muslims. Yet again, according to the forecast of the organization Christian Research, by 2020 another 4000 temples will be closed in England. According to the British Guardian, the reason for this was the reduction in church attendance to 760,000 on Sunday. Also, according to Spiegel, only 340 churches were closed at the Evangelical Church of Germany from 1990 to 2010, they were turned into buildings for various purposes. At this day's the same transformation of mosques into churches has been observed in European Muslim countries. At the moment, there are 117 mosques in Bulgaria, more than six mausoleums and madrassas, three mosques and a chapel in Croatia, six mosques and mausoleums in Crimea, 23 mosques in Hungary, 5 mausoleums, a bathhouse and one school of the Ottoman Empire were forcibly turned into churches. In general, the article provides examples of several basic taxes imposed on zimmis to study the main zimmi taxes in the Middle Ages. Another area of research is the problem of general and special in the concept of taxation of Islam and Christianity. The work is aimed, firstly, at the interpretation of differences and similarities to Islamic religions and dominant religions flourishing in this era of European countries; secondly, on understanding the specifics of the relationship of Christian and Islamic cultures to the "infidels", "nonbelievers".

I hope that these studies can be used in the development and teaching of general and specialized courses on the history and culture of Arab-Islamic and Western European civilizations in the Middle Ages, in courses on the history and theory of Islamic-Christian, Islamic-Jewish intercultural dialogue, as well as will serve as material for improving interreligious relations in Central Asia.

Key Words: Islam, Christianity, Judaism, People of the Book, Zimmi, Taxes 